\title{
FOZO, HIMU, and the rest of the mantle zoo
}

\author{
Andreas Stracke and Albrecht W. Hofmann \\ Max-Planck-Institut für Chemie, Postfach 3060, 55020 Mainz, Germany \\ (stracke@mpch-mainz.mpg.de; hofmann@mpch-mainz.mpg.de)
}

\author{
Stan R. Hart \\ Woods Hole Oceanographic Institution, 266 Woods Hole Road, Woods Hole, Massachusetts 02543, USA \\ (shart@whoi.edu)
}

[1] The parameter $\mu$ describes the ${ }^{238} \mathrm{U} /{ }^{204} \mathrm{~Pb}$ ratio of an Earth reservoir. Mantle domains labeled HIMU (high $\mu$ ) originally defined reservoirs with highly radiogenic $\mathrm{Pb}$ isotope ratios observed in basalts from a select number of ocean islands, St. Helena in the Atlantic Ocean and the Cook-Austral islands in the South Pacific Ocean. While some authors use the term HIMU in this original sense, others refer to HIMU as a widespread component in many mid-ocean ridge and ocean island basalt (MORB and OIB) sources. Here we show that highly radiogenic $\mathrm{Pb}$ isotope signatures in MORB and OIB originate from two different sources. In addition to the classical HIMU component observed at St. Helena and the South Pacific (named HIMU in the following), we define a component with slightly less radiogenic $\mathrm{Pb}$ but significantly more radiogenic $\mathrm{Sr}$ isotope signatures. This component lies at the extension of the (Atlantic and Pacific) MORB array in a $\mathrm{Sr}-\mathrm{Pb}$ isotope ratio diagram and is argued to be a ubiquitous component in MORB and many OIB sources. The inferred role of this component in the mantle and its inferred genetic origin closely resemble those originally suggested for a mantle component termed FOZO by Hart and coworkers. By redefining the composition, the origin, and the role of FOZO in the mantle, we establish a simple conceptual framework that explains the isotopic variability in both MORB and OIB with the lowest number of components. OIB are grouped into HIMU-type OIB and basalts from islands that diverge from the MORB-FOZO array toward various isotopically "enriched" compositions (EM). The apparent ubiquity of FOZO in the mantle and the calculated isotopic evolution of compositionally diverse MORB suggest that normal mantle melting and continuous subduction and aging of that crust during recycling through the mantle are the dominant causes of the MORB-FOZO array. In contrast to FOZO, HIMU-type OIB are quite rare, and if an origin by recycling of oceanic crust is also postulated, the production of HIMU sources has to be a special and rare combination of age and composition of subduction-modified recycled oceanic crust.

Components: 10,344 words, 10 figures, 1 animation.

Keywords: FOZO; HIMU; MORB; oceanic basalts; OIB.

Index Terms: 1038 Geochemistry: Mantle processes (3621); 1025 Geochemistry: Composition of the mantle; 1030 Geochemistry: Geochemical cycles (0330); 1040 Geochemistry: Radiogenic isotope geochemistry; 1212 Geodesy and Gravity: Earth's interior: composition and state $(7207,7208,8105,8124)$.

Received 26 August 2004; Revised 14 March 2005; Accepted 23 March 2005; Published 19 May 2005.

Stracke, A., A. W. Hofmann, and S. R. Hart (2005), FOZO, HIMU, and the rest of the mantle zoo, Geochem. Geophys. Geosyst., 6, Q05007, doi:10.1029/2004GC000824. 


\section{Introduction}

[2] It has been known for more than 30 years that many mid-ocean ridge and ocean island basalts (MORB and OIB) contain variably radiogenic lead, which requires a history of relatively high $\mathrm{U} / \mathrm{Pb}$ and $\mathrm{Th} / \mathrm{Pb}$ ratios in their sources [e.g., Gast et al., 1964; Armstrong, 1968; Gast, 1968; Tatsumoto, 1978; Sun, 1980; Zindler and Hart, 1986; Hanan and Graham, 1996; Hofmann, 1997]. While there is extensive overlap between $\mathrm{Pb}$ isotope ratios in MORB and OIB, the most radiogenic $\mathrm{Pb}$ isotope ratios are found in OIB, which have been classified as HIMU-type OIB [Zindler and Hart, 1986]. HIMU is geochemical jargon for "high- $\mu$," with $\mu$ being defined as $\mu=\left({ }^{238} \mathrm{U} / 204 \mathrm{~Pb}\right)_{\mathrm{t}=0}$ [Houtermans, 1953; Zindler and Hart, 1986]. Although ${ }^{238} \mathrm{U} /{ }^{204} \mathrm{~Pb}$ ratios change significantly with time, $\mu$ is defined as the present-day (i.e., zero-age, $t=0$ ) ${ }^{238} \mathrm{U} /{ }^{204} \mathrm{~Pb}$ ratio by convention.

[3] The HIMU effect is part of the so-called "lead paradox," which concerns the fact that $\mathrm{Pb}$ isotope ratios in most MORB and OIB are more radiogenic than in the undifferentiated mantle or bulk Earth. This is contrary to expected geochemical systematics, which dictate that the highly incompatible uranium should be more depleted than the moderately incompatible lead in the depleted mantle [Allègre, 1969]. Several solutions have been proposed to explain this effect, for example late transport of lead into the core [Vollmer, 1977; Vidal and Dosso, 1978; Allègre et al., 1980; Vidal et al., 1984], hydrothermal transfer of lead from mantle to continental crust [Peucker-Ehrenbrink et al., 1994; Chauvel et al., 1995; Hofmann, 1997], uranium uptake by the subducted oceanic crust [Hofmann and White, 1980; Elliott et al., 1999], and an age of the mantle that is significantly younger than the ages of meteorites [Zartman and Haines, 1988].

[4] Independent of what the correct explanation for the radiogenic $\mathrm{Pb}$ isotope ratios in MORB and OIB is in general, the most radiogenic $\mathrm{Pb}$ isotope signatures in MORB and OIB are widely ascribed to a HIMU-type source component. This HIMU component is thought to be a mantle component with a common origin. In the following, we use the term "component" to characterize parts of the mantle that are isotopically different from other parts of the mantle, with no implications about their physical size and properties, mineralogic composition, genetic origin, or location and distribution in the mantle. Recently, Hoernle et al.
[1995] and Wilson et al. [1995] suggested that a HIMU component is ubiquitous in the upper mantle beneath much of the Atlantic Ocean, Europe and the Mediterranean Sea. Such a ubiquitous presence of a component with HIMU-like affinities, though not necessarily restricted to the upper mantle, had previously been suggested by Hart et al. [1992] (see also discussion below) and also by Stracke et al. [2003b]; it is also implied by the modeling study of Christensen and Hofmann [1994]. Vidal [1992] and Thirlwall [1995, 1997] further suggested that variously radiogenic lead in OIB can originate from continuously produced high- $\mu$ materials.

[5] Here, we argue that the radiogenic lead found in MORB and many OIB is likely to originate from a different type of source compared to the source with the most radiogenic $\mathrm{Pb}$ isotope ratios found in "classical" HIMU-type OIB, such as occur on St. Helena and some of the Cook-Austral Islands (e.g., Tubuai, Mangaia and Rurutu). St. Helena and the Cook-Austral-type HIMU OIB sources (in the following simply referred to as HIMU) do not, in fact, appear to significantly contribute to the isotope arrays found in MORB and other OIB, and may ultimately be derived from a single reservoir that is different from that of the "HIMU-type" component found in MORB and many other OIB. The systematics of MORB and OIB isotope arrays suggest that the radiogenic lead in MORB and OIB, with the exception of the St. Helena and Cook-Austral HIMU OIB, derive from a common component that is ubiquitous in both MORB and OIB mantle sources. To give credit to the first proposal of such a ubiquitous component we adhere to the term FOZO after Hart et al. [1992]. By redefining the composition, the origin, and the role of FOZO in the mantle, we establish a simple conceptual framework that explains the isotopic variability in both MORB and OIB with the lowest number of components. These are depleted MORB mantle (DMM), HIMU, two varieties of enriched mantle (EM 1 and EM 2 [Zindler and Hart, 1986]), and FOZO, as redefined in this study.

\section{Two Different HIMU Components in the Mantle}

[6] Depicting and analyzing isotopic relationships in mantle-derived basalts has become difficult because of the large amount of data available and because of the large number of parameters that can be evaluated. Principal component analysis as used by Allegre et al. [1987] is probably the most 
efficient way to display the extreme mixing endmembers, but its high degree of abstraction makes it somewhat counterintuitive. Moreover, it is difficult with this technique to identify possible mixing components that may be located at intermediate rather than extreme compositions, because a physically present mixing component of such intermediate composition is likely to be interpreted as a mixture between the "principal," extreme compositions. The three-dimensional tetrahedron representation chosen by Hart et al. [1992] used envelopes for data from individual hot spots, and such envelopes might be biased by a small number of samples (a single one in the extreme case). The triangular representation chosen by Hanan and Graham [1996] does not show the separation between different MORB (and OIB) arrays any more clearly than do conventional x-y diagrams. For these reasons, we use two and three-dimensional isotope ratio plots of real data throughout this paper, which are based on a more recent data compilation for global MORB and OIB [Stracke et al., 2003a] compared to that introduced by Hofmann [1997]. This data set includes only samples with $\mathrm{Sr}, \mathrm{Nd}$ and $\mathrm{Pb}$ isotopes determined on the same sample and consists of more than 1000 MORB data from all three major oceans and more than 2000 OIB data.

[7] The term HIMU has often been used loosely for basalts with ${ }^{206} \mathrm{~Pb} /{ }^{204} \mathrm{~Pb}$ ratios greater than about 19.5. However, OIB with the most radiogenic lead isotope ratios must actually be divided into two groups (Figure 1): The first group is characterized by the most radiogenic $\mathrm{Pb}$ isotope signatures among MORB and OIB $\left({ }^{206} \mathrm{~Pb} /{ }^{204} \mathrm{~Pb}\right.$ $>20.5)$ and relatively low ${ }^{87} \mathrm{Sr} /{ }^{86} \mathrm{Sr} \quad(<0.703)$ [Zindler and Hart, 1986; Hart, 1988; Vidal, 1992]. It is represented in basalts from St. Helena and from Mangaia, Rurutu (old volcanics), Rimatara, Raivavae, and Tubaii of the Cook-Austral islands (hereafter referred to as HIMU; Figure 1, red symbols). The second group is characterized by slightly less radiogenic $\mathrm{Pb}$ isotope ratios, but more radiogenic $\mathrm{Sr}$ isotope ratios $\left({ }^{206} \mathrm{~Pb} /{ }^{204} \mathrm{~Pb}=\right.$ $19.5-20.5$ and ${ }^{87} \mathrm{Sr} /{ }^{86} \mathrm{Sr}=0.7028-0.7034$, respectively); it overlaps and extends the trend of MORB in a ${ }^{206} \mathrm{~Pb} /{ }^{204} \mathrm{~Pb}$ or ${ }^{208} \mathrm{~Pb} /{ }^{206} \mathrm{~Pb}$ versus ${ }^{87} \mathrm{Sr} /{ }^{86} \mathrm{Sr}$ diagram (Figure 1). This moderately HIMU-like component is represented in basalts from the islands of Rurutu (young volcanics only), Mauke, Rimatara and Raivavae of the Cook-Austral chain (Figure 1, green symbols).

[8] Not surprisingly, within the zoo of mantle components, this moderately HIMU-like source has some resemblance with a number of previously discussed mantle components. Most prominently, it closely resembles "FOZO" (FOcal ZOne), first defined by Hart et al. [1992]. The composition of FOZO, as defined by Hart et al. [1992], has long been a moving target, spanning a range of isotopic compositions from originally depleted $\mathrm{Sr}$ and $\mathrm{Nd}$ and fairly radiogenic $\mathrm{Pb}$ isotope ratios $\left({ }^{87} \mathrm{Sr} /{ }^{86} \mathrm{Sr}<0.7025,{ }^{143} \mathrm{Nd} /{ }^{144} \mathrm{Nd}>0.5131\right.$, and ${ }^{206} \mathrm{~Pb} /{ }^{204} \mathrm{~Pb} \approx 19.1-19.7$ [Hart et al., 1992]) to more moderate $\mathrm{Sr}, \mathrm{Nd}$, and $\mathrm{Pb}$ isotope ratios $\left({ }^{87} \mathrm{Sr} /{ }^{86} \mathrm{Sr}=0.703-0.704,{ }^{143} \mathrm{Nd} /{ }^{144} \mathrm{Nd}=\right.$ $0.5128-0.5130,{ }^{206} \mathrm{~Pb} /{ }^{204} \mathrm{~Pb}=18.5-19.5$, ${ }^{207} \mathrm{~Pb} /{ }^{204} \mathrm{~Pb}=15.55-15.65,{ }^{208} \mathrm{~Pb} /{ }^{204} \mathrm{~Pb}=38.8-$ 39.3; [Hauri et al., 1994]) and back to fairly radiogenic $\mathrm{Pb}$ and unradiogenic $\mathrm{Sr}$ isotope ratios $\left({ }^{206} \mathrm{~Pb} /{ }^{204} \mathrm{~Pb}=19.4,{ }^{87} \mathrm{Sr} /{ }^{86} \mathrm{Sr}=0.7030-0.7032\right.$ [Workman et al., 2004]; Figure 2). The moderately HIMU-like compositions of the second group defined above (Figures 1 and 2, green symbols) overlap with the most recent composition suggested for FOZO [Workman et al., 2004] (Figure 2). It will become clear from the following discussion that the inferred role of such moderately HIMUlike compositions in the mantle (see above and Figures 1 and 2, green symbols) and their inferred genetic origin also closely resemble those originally suggested for FOZO [Hart et al., 1992]. We will thus hereafter refer to such isotopic compositions as FOZO.

\section{Systematics of MORB and OIB Isotope Arrays}

[9] Figure 3 shows $\mathrm{Pb}$ isotope data conventionally plotted on a "Holmes-Houtermans" type diagram. The ${ }^{207} \mathrm{~Pb} /{ }^{204} \mathrm{~Pb}-{ }^{206} \mathrm{~Pb} /{ }^{204} \mathrm{~Pb}$ diagram shows the main reason for the notion that HIMU-type sources (as defined above, i.e., the St. Helena and CookAustral HIMU sources) are a mixing component in MORB (Figure 3a). The broad linear trend in the ${ }^{207} \mathrm{~Pb} /{ }^{204} \mathrm{~Pb}-{ }^{206} \mathrm{~Pb} /{ }^{204} \mathrm{~Pb}$ diagram can be produced, in principle, by a single differentiation event about 1.8 to 2 Gyr ago [Tatsumoto, 1978; Sun, 1980] or, more likely, by a process of continuous differentiation of $\mathrm{U}-\mathrm{Pb}$ ratios and convective remixing as suggested by Allègre et al. [1980] and Christensen and Hofmann [1994]. The companion plot of ${ }^{208} \mathrm{~Pb} /{ }^{204} \mathrm{~Pb}-{ }^{206} \mathrm{~Pb} /{ }^{204} \mathrm{~Pb}$, however, shows that MORB and FOZO on one hand and the HIMU data on the other form two distinct arrays with different slopes (Figure 3b). A hypothetical mixing line drawn between HIMU and a depleted MORB end-member is not populated by actual 

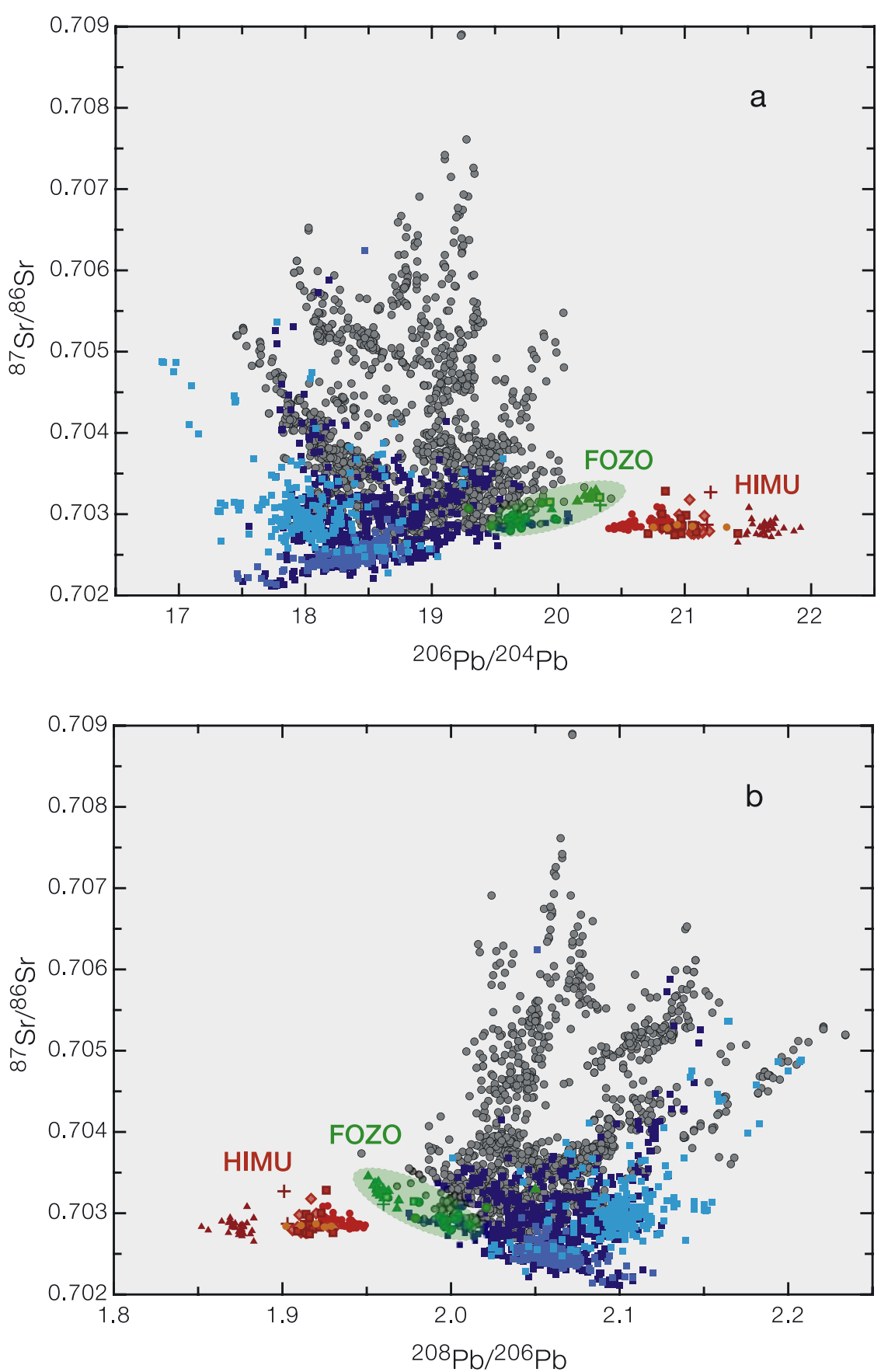

\section{MORB}

- Atlantic MORB

- Pacific MORB

- Indian MORB

Non-HIMU type OIB

- OIB

HIMU

- St. Helena

- Tubuai

- Rurutu old volcanics

- Mangaia

+ Rimatara HIMU

- Raivavae HIMU

FOZO

- Rurutu young volcanics

+ Rimatara FOZO

- Mauke FOZO

- Raivavae FOZO

Figure 1. Diagrams of (a) ${ }^{206} \mathrm{~Pb} /{ }^{204} \mathrm{~Pb}$ versus ${ }^{87} \mathrm{Sr} /{ }^{86} \mathrm{Sr}$ and (b) ${ }^{208} \mathrm{~Pb} /{ }^{206} \mathrm{~Pb}$ versus ${ }^{87} \mathrm{Sr} /{ }^{86} \mathrm{Sr}$ suggest that HIMU-type sources can be divided into two different types. One is characterized by the most radiogenic $\mathrm{Pb}$ isotope signatures among MORB and OIB $\left({ }^{206} \mathrm{~Pb} /{ }^{204} \mathrm{~Pb}>20.5\right)$ and relatively low ${ }^{87} \mathrm{Sr} /{ }^{86} \mathrm{Sr}(<0.703)$ and is represented by basalts from St. Helena and from Mangaia, Rurutu (old volcanics), Rimatara, Raivavae, and Tubaii island of the Cook-Austral chain (HIMU, red symbols). The other HIMU-type source, FOZO (green symbols and shaded green field), extends the MORB trend and is characterized by moderately radiogenic $\mathrm{Pb}\left({ }^{206} \mathrm{~Pb} /{ }^{204} \mathrm{~Pb}=19.5-20.5\right)$ and $\mathrm{Sr}$ isotope ratios $\left({ }^{87} \mathrm{Sr} /{ }^{86} \mathrm{Sr}=0.7028-0.7034\right)$ and is represented in basalts from the islands of Rurutu (young volcanics only), Mauke, Rimatara, and Raivavae of the Cook-Austral chain. Data compilation can be obtained from Stracke et al. [2003a].

data (Figure 3b, dashed line). Plots of, for example, ${ }^{208} \mathrm{~Pb} * 206 \mathrm{~Pb} *$ versus ${ }^{206} \mathrm{~Pb} /{ }^{204} \mathrm{~Pb}$ and ${ }^{208} \mathrm{~Pb} / 206 \mathrm{~Pb}$ versus ${ }^{207} \mathrm{~Pb} /{ }^{206} \mathrm{~Pb}$ (Figure 4), as well as ${ }^{206} \mathrm{~Pb} /{ }^{204} \mathrm{~Pb}$ and ${ }^{208} \mathrm{~Pb} /{ }^{206} \mathrm{~Pb}$ versus ${ }^{143} \mathrm{Nd} /{ }^{144} \mathrm{Nd}$ (Figure 5), confirm the difference between HIMU and FOZO and suggest that the low ${ }^{206} \mathrm{~Pb} /{ }^{204} \mathrm{~Pb}$ end-members of the MORB arrays mix with FOZO but not with HIMU (compare green and red symbols in 


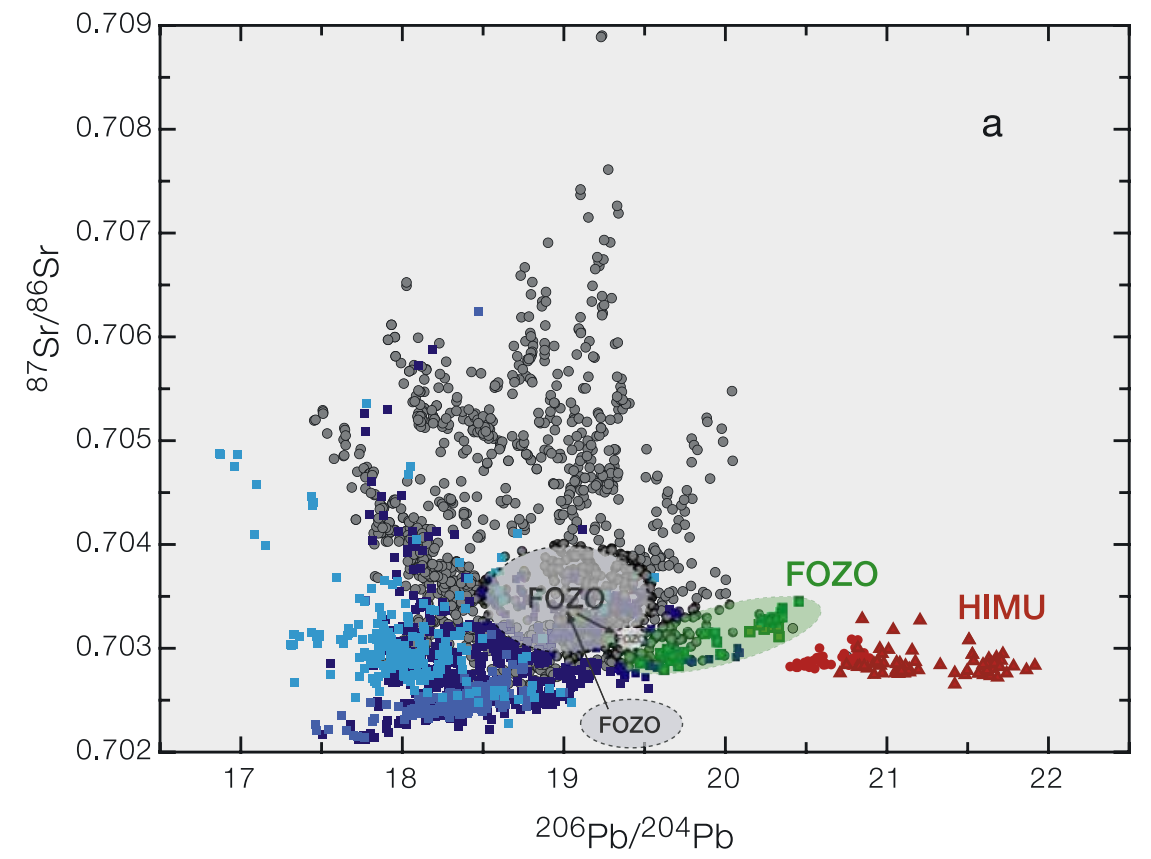

\section{MORB}

- Atlantic MORB

- Pacific MORB

- Indian MORB

Non-HIMU type OIB

- OIB

HIMU

- St. Helena

- Cook-Austral HIMU

FOZO

- Cook-Austral FOZO-type

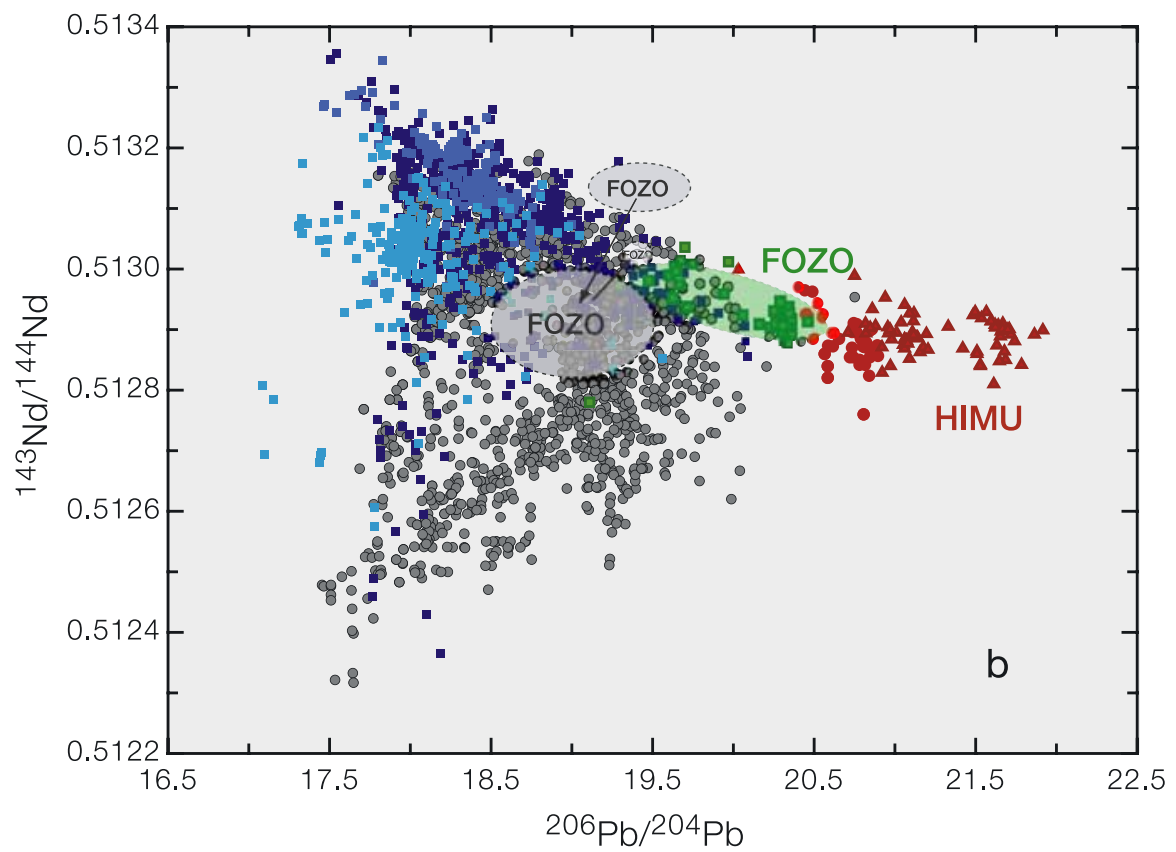

Figure 2. Plots of (a) ${ }^{206} \mathrm{~Pb} /{ }^{204} \mathrm{~Pb}$ versus ${ }^{87} \mathrm{Sr} /{ }^{86} \mathrm{Sr}$ and (b) ${ }^{206} \mathrm{~Pb} /{ }^{204} \mathrm{~Pb}$ versus ${ }^{143} \mathrm{Nd} /{ }^{144} \mathrm{Nd}$. The shaded regions labeled FOZO show the progressive evolution of the composition and inherent conceptual evolution of the FOZO concept. The shaded green field shows the FOZO composition as redefined here. Gray shaded fields show previous definitions of $\mathrm{FOZO}$ by Hart et al. [1992], ranging from originally depleted $\mathrm{Sr}$ and $\mathrm{Nd}$ and fairly radiogenic $\mathrm{Pb}$ isotope ratios $\left({ }^{87} \mathrm{Sr} /{ }^{86} \mathrm{Sr}<0.7025,{ }^{143} \mathrm{Nd} /{ }^{144} \mathrm{Nd}>0.5131\right.$, and ${ }^{206} \mathrm{~Pb} /{ }^{204} \mathrm{~Pb} \approx 19.1-19.7$, respectively [Hart et al., 1992]) to more moderate $\mathrm{Sr}, \mathrm{Nd}$, and $\mathrm{Pb}$ isotope ratios $\left({ }^{87} \mathrm{Sr} /{ }^{86} \mathrm{Sr}=0.703-0.704,{ }^{143} \mathrm{Nd} /{ }^{144} \mathrm{Nd}=0.5128-0.5130\right.$, ${ }^{206} \mathrm{~Pb} /{ }^{204} \mathrm{~Pb}=18.5-19.5,{ }^{207} \mathrm{~Pb} /{ }^{204} \mathrm{~Pb}=15.55-15.65,{ }^{208} \mathrm{~Pb} /{ }^{204} \mathrm{~Pb}=38.8-39.3$ [Hauri et al., 1994]) and back to fairly radiogenic $\mathrm{Pb}$ and unradiogenic $\mathrm{Sr}$ isotope ratios $\left({ }^{206} \mathrm{~Pb} /{ }^{204} \mathrm{~Pb}=19.4,{ }^{87} \mathrm{Sr} /{ }^{86} \mathrm{Sr}=0.7030-0.7032[\right.$ Workman et al., 2004]). 


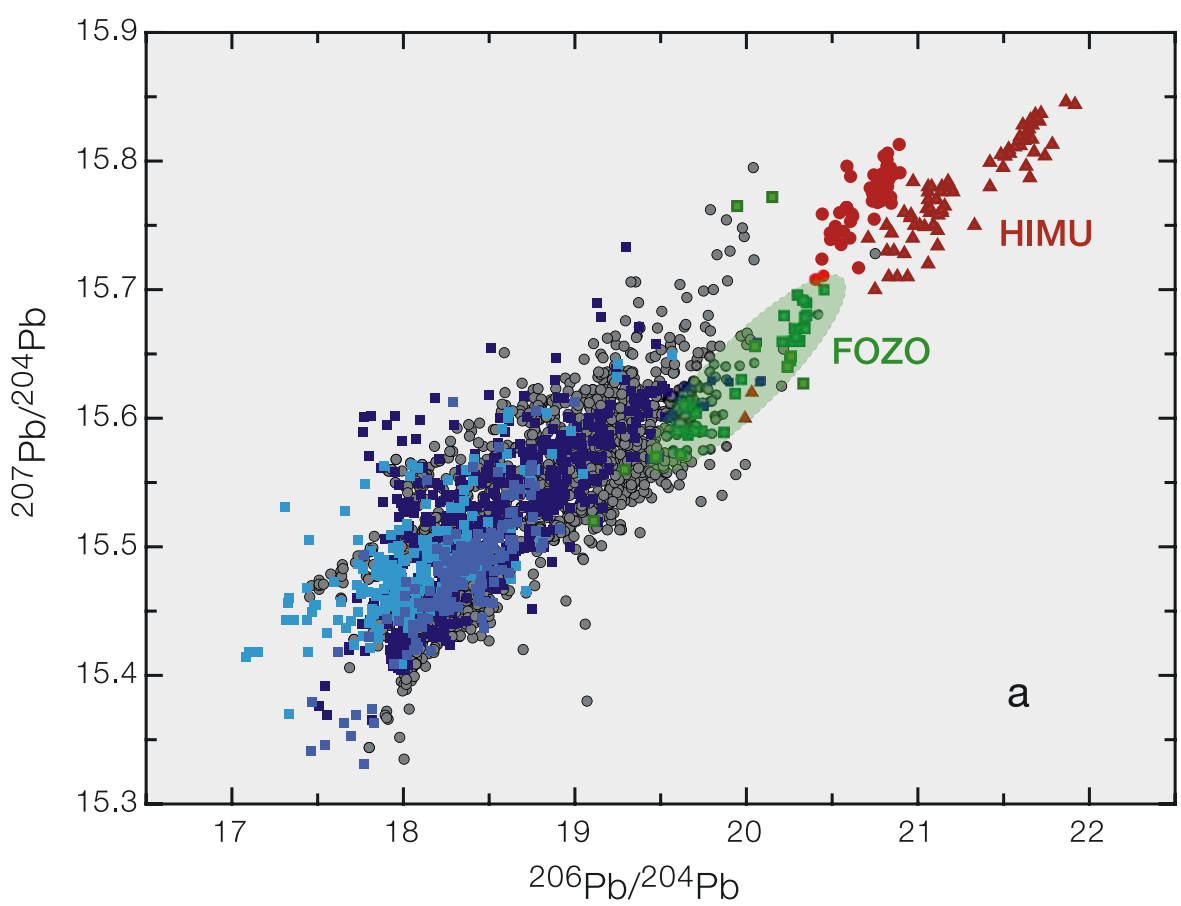

\section{MORB}

- Atlantic MORB

- Pacific MORB

- Indian MORB

Non-HIMU type OIB

- OIB

HIMU

- St. Helena

- Cook-Austral HIMU

FOZO

- Cook-Austral FOZO

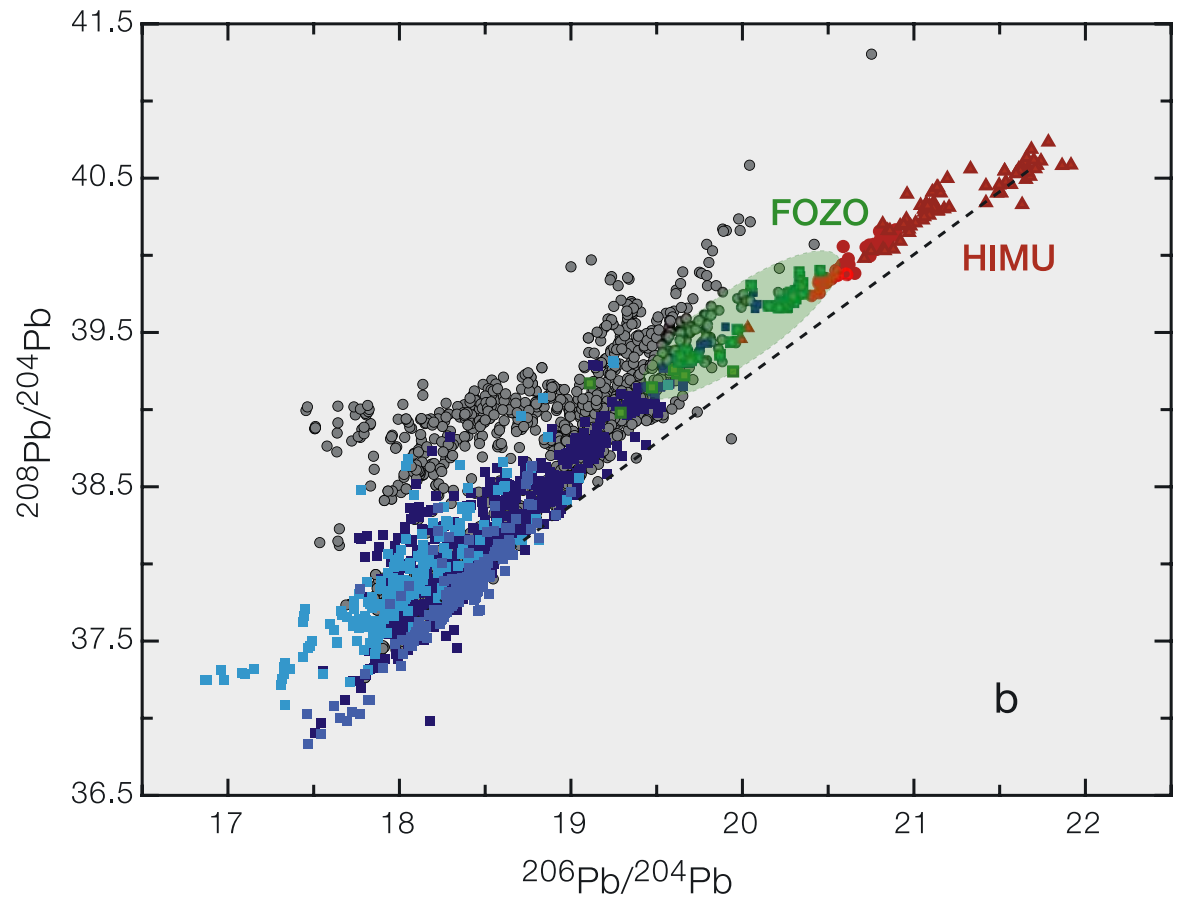

Figure 3. Plots of (a) ${ }^{206} \mathrm{~Pb} /{ }^{204} \mathrm{~Pb}$ versus ${ }^{207} \mathrm{~Pb} /{ }^{204} \mathrm{~Pb}$ and (b) ${ }^{206} \mathrm{~Pb} /{ }^{204} \mathrm{~Pb}$ versus ${ }^{208} \mathrm{~Pb} /{ }^{204} \mathrm{~Pb}$ for global MORB and OIB. While it appears possible from a ${ }^{206} \mathrm{~Pb} /{ }^{204} \mathrm{~Pb}$ versus ${ }^{207} \mathrm{~Pb} /{ }^{204} \mathrm{~Pb}$ diagram (Figure $3 \mathrm{a}$ ) that OIB are mixtures between HIMU and MORB sources, the ${ }^{206} \mathrm{~Pb} /{ }^{204} \mathrm{~Pb}$ versus ${ }^{208} \mathrm{~Pb} /{ }^{204} \mathrm{~Pb}$ diagram shows that a hypothetical mixing line drawn between HIMU and a depleted MORB end-member is not populated by actual data (Figure $3 \mathrm{~b}$, dashed line). Thus mixing between MORB- and HIMU-type sources is unlikely to be the major cause for the Pb isotope variability in MORB and OIB. FOZO-like compositions are indicated by the shaded green field. 


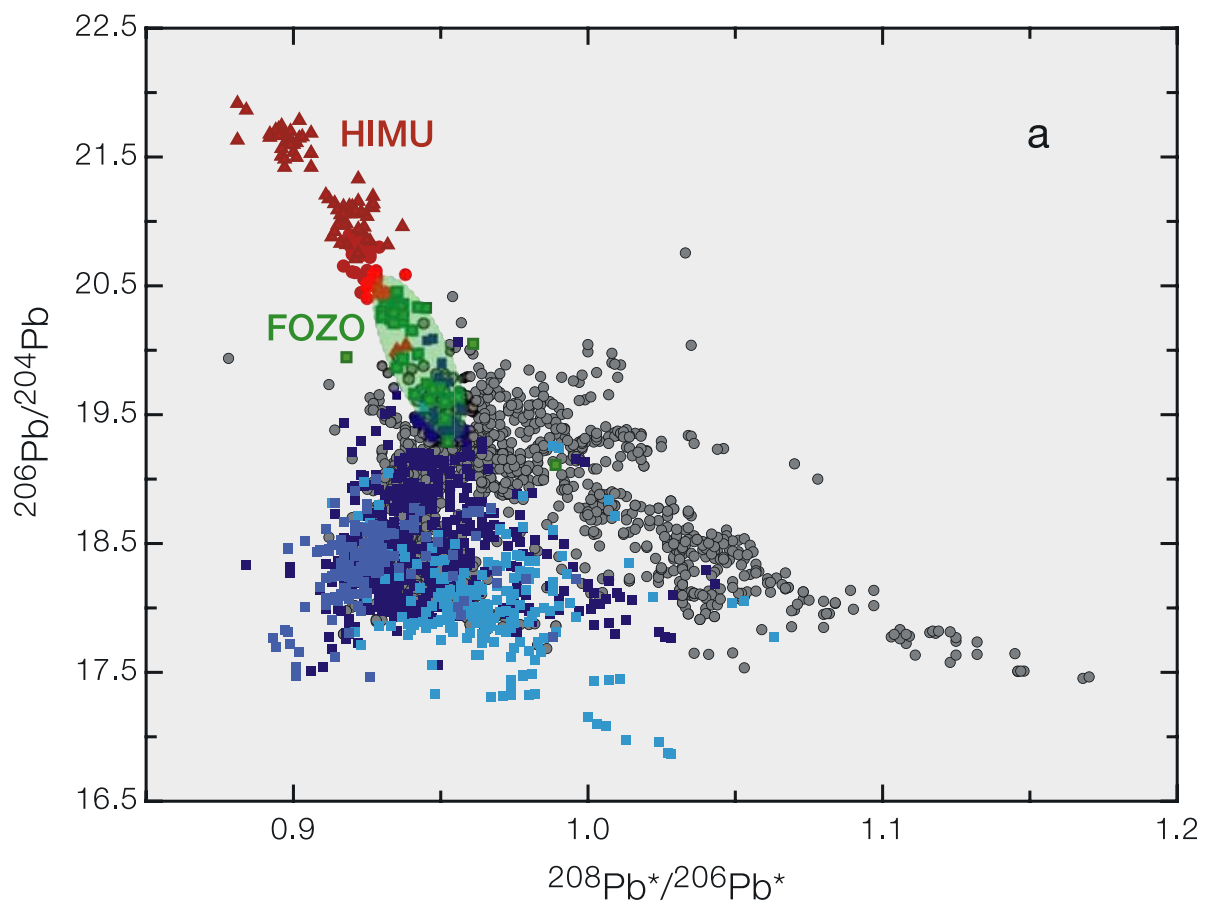

\section{MORB}

- Atlantic MORB

- Pacific MORB

- Indian MORB

Non-HIMU type OIB

- OIB

HIMU

- St. Helena

$\triangle$ Cook-Austral HIMU

FOZO

- Cook-Austral FOZO

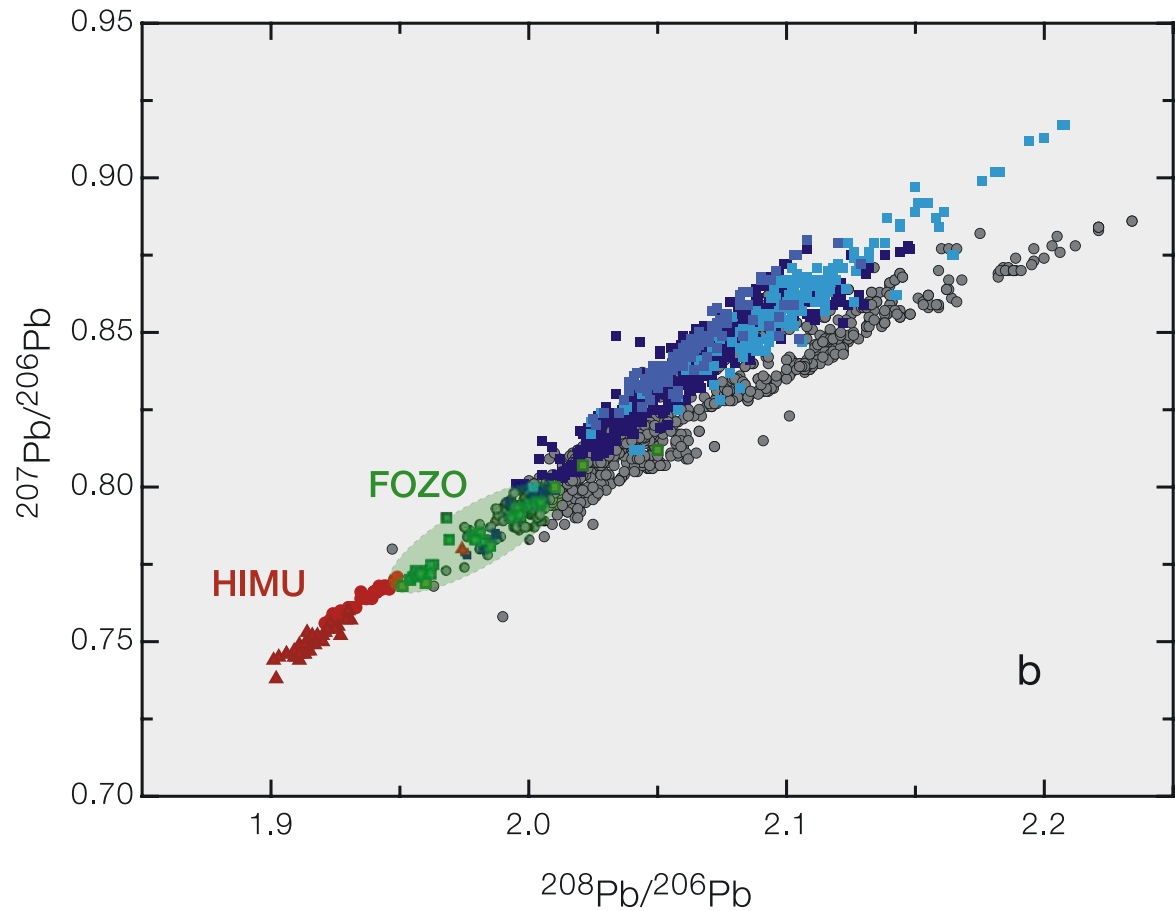

Figure 4. Plots of (a) ${ }^{208} \mathrm{~Pb} * / 206 \mathrm{~Pb} *$ versus ${ }^{206} \mathrm{~Pb} /{ }^{204} \mathrm{~Pb}$ and (b) ${ }^{208} \mathrm{~Pb} /{ }^{206} \mathrm{~Pb}$ versus ${ }^{207} \mathrm{~Pb} /{ }^{206} \mathrm{~Pb}$ show the difference between FOZO- and HIMU-type sources.

Figures $2-4 ;{ }^{208} \mathrm{~Pb} * 206 \mathrm{~Pb}^{*}=\left({ }^{208} \mathrm{~Pb} /{ }^{204} \mathrm{~Pb}_{\text {measured }}-\right.$ $29.476) /\left({ }^{206} \mathrm{~Pb} /{ }^{204} \mathrm{~Pb}_{\text {measured }}\right.$ - 9.307) [Galer and O'Nions, 1985]). Plots of ${ }^{208} \mathrm{~Pb}^{*} /{ }^{206} \mathrm{~Pb}^{*}$ and ${ }^{87} \mathrm{Sr} /{ }^{86} \mathrm{Sr}$ versus ${ }^{176} \mathrm{Hf} /{ }^{177} \mathrm{Hf}$ ratios also show the unique composition of HIMU amongst MORB and OIB (Figure 6, red symbols).
[10] The apparent convergence of OIB trends in two or three dimensional isotope ratio space has led to the original postulation and definition of FOZO [Hart et al., 1992] as a suitable end-member of numerous OIB, but not MORB, isotope arrays. It is debatable, however, whether or not OIB trends 

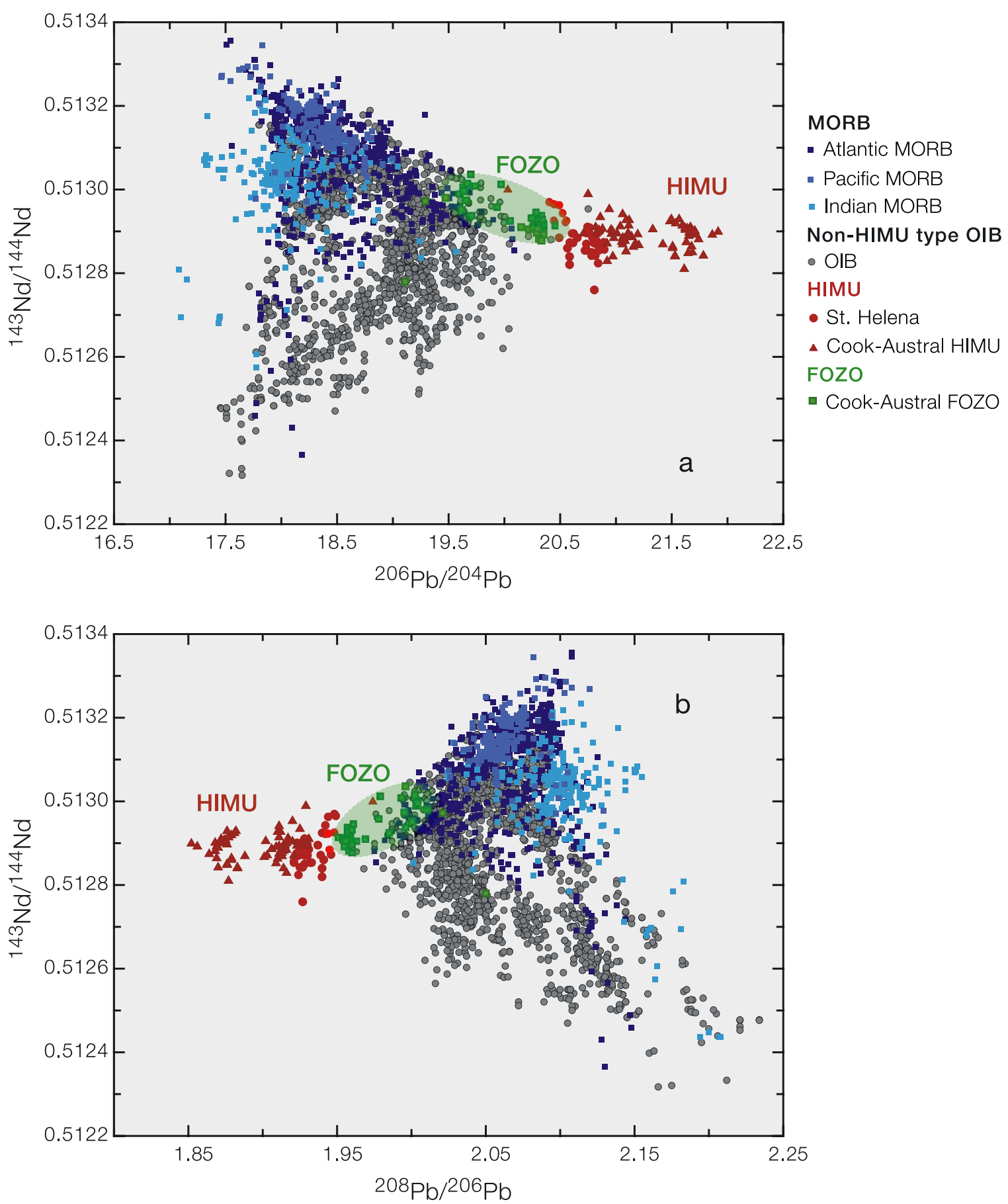

Figure 5. Plots of (a) ${ }^{206} \mathrm{~Pb} /{ }^{204} \mathrm{~Pb}$ versus ${ }^{143} \mathrm{Nd} /{ }^{144} \mathrm{Nd}$ and (b) ${ }^{208} \mathrm{~Pb} /{ }^{206} \mathrm{~Pb}$ versus ${ }^{143} \mathrm{Nd} /{ }^{144} \mathrm{Nd}$ show that HIMUtype sources are distinct from other MORB and OIB sources.

really do converge into a restricted region in two or three dimensional isotope space (see Figures 1-6 and Stracke et al. [2003b]). By redefining the isotopic composition of FOZO to overlap and extend the MORB array in a ${ }^{206} \mathrm{~Pb} /{ }^{204} \mathrm{~Pb}$ or ${ }^{208} \mathrm{~Pb} /{ }^{206} \mathrm{~Pb}$ versus ${ }^{87} \mathrm{Sr} /{ }^{86} \mathrm{Sr}$ diagram (Figure 1, see discussion above), FOZO becomes, by defini- tion, a suitable component to explain the isotopic variability in MORB.

[11] In each of the diagrams shown in Figures 1-6, Pacific MORB form the tightest array with strong linear correlations between FOZO and a depleted component. Atlantic MORB show wider scatter 


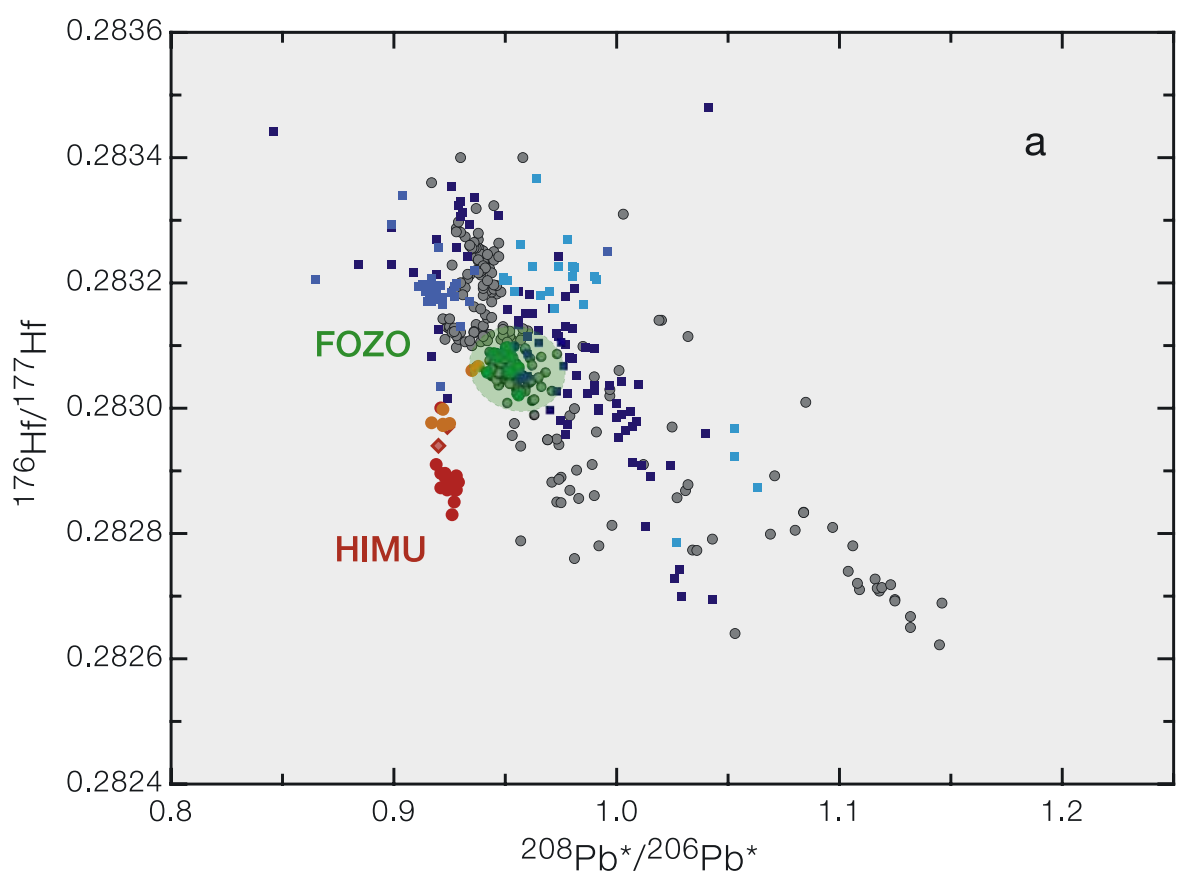

\section{MORB}

- Atlantic MORB

- Pacific MORB

- Indian MORB

Non-HIMU type OIB

- OIB

HIMU

- St. Helena

- Tubuai

- Raivavae HIMU

FOZO

- Raivavae FOZO

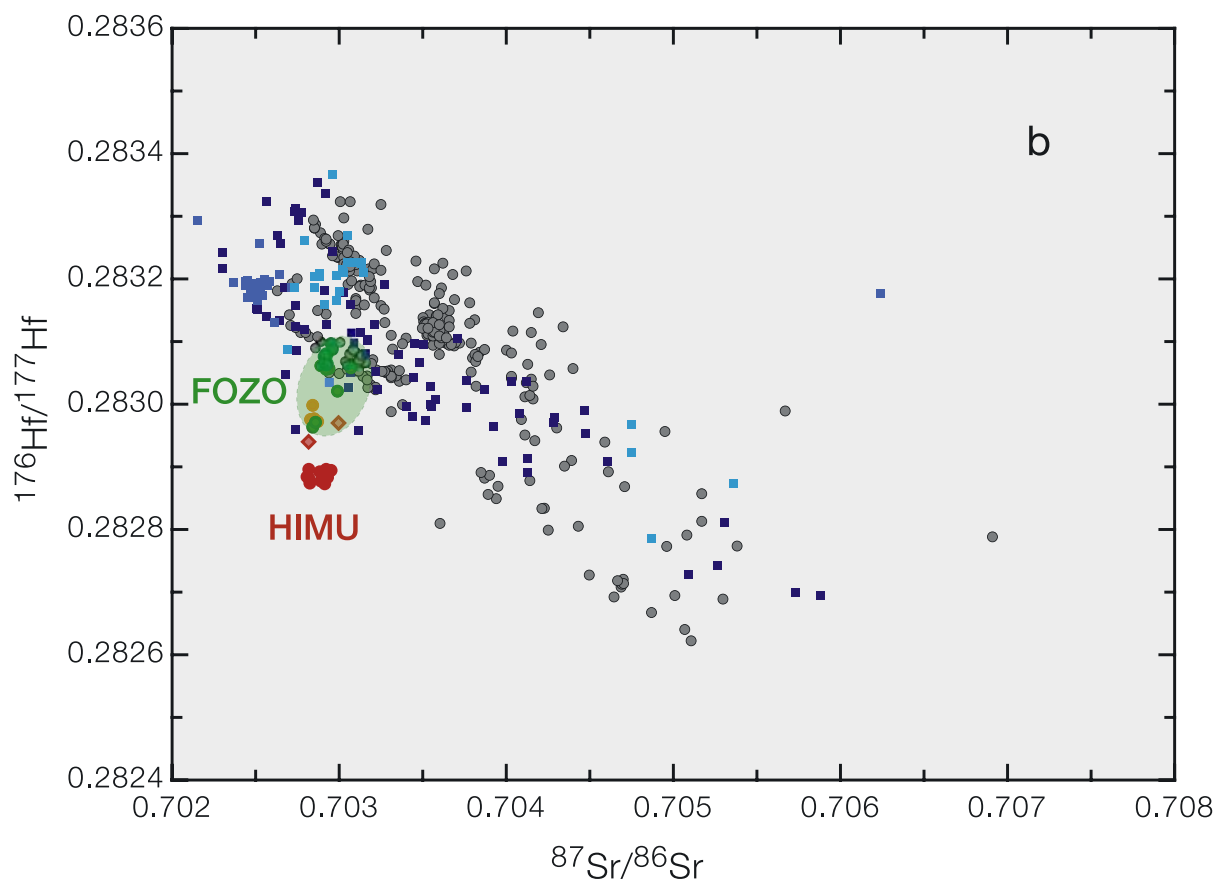

Figure 6. Plots of (a) ${ }^{208} \mathrm{~Pb}^{*} /{ }^{206} \mathrm{~Pb} *$ and (b) ${ }^{87} \mathrm{Sr} /{ }^{86} \mathrm{Sr}$ versus ${ }^{176} \mathrm{Hf} /{ }^{177} \mathrm{Hf}$. FOZO basalts have higher ${ }^{176} \mathrm{Hf} /{ }^{177} \mathrm{Hf}$ ratios than HIMU basalts for given ${ }^{208} \mathrm{~Pb}^{*} /{ }^{206} \mathrm{~Pb}^{*}$ and ${ }^{87} \mathrm{Sr} /{ }^{86} \mathrm{Sr}$. Note that the limited amount of samples available with ${ }^{176} \mathrm{Hf} /{ }^{177} \mathrm{Hf}$ may distort the range for FOZO-like compositions compared to Figures $1-5$ and that the arrays in Figures $6 \mathrm{a}$ and $6 \mathrm{~b}$ have a different range because $\mathrm{Sr}$ isotopes are not available for all samples with $\mathrm{Hf}$ and $\mathrm{Pb}$ isotopes determined on the same sample.

but when neglecting outliers similar correlations between FOZO and a depleted component as Pacific MORB. In contrast, Indian MORB are different with much wider scatter and very loose correlations in some diagrams and no correlation in others. The sub-Indian Ocean upper mantle is clearly different from both the Atlantic and Pacific upper mantle and is possibly contaminated with ancient sediments [Rehkämper and Hofmann, 1997], delaminated subcontinental lithosphere 


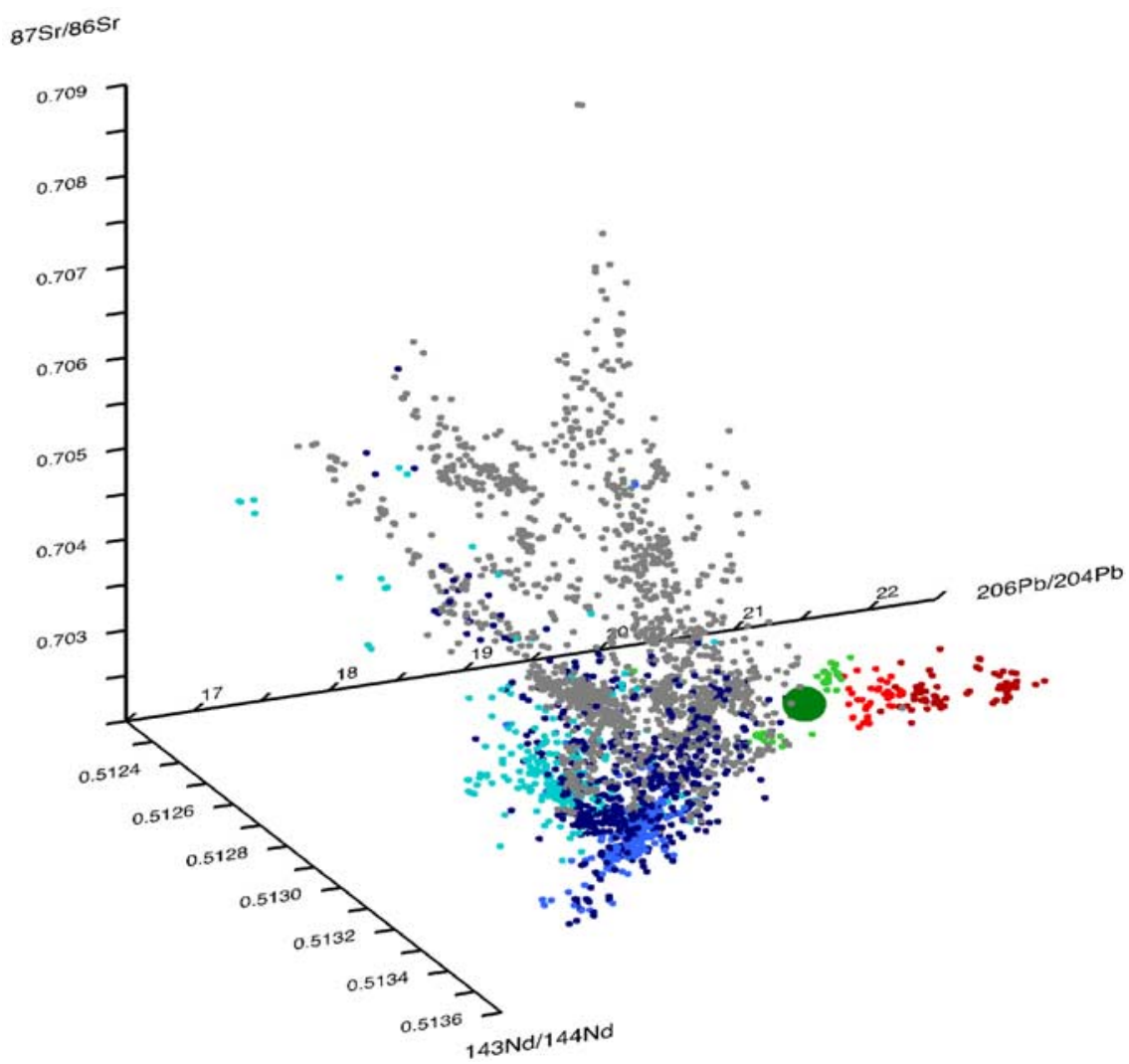

Figure 7. MORB and OIB isotope arrays plotted in three dimensions with ${ }^{143} \mathrm{Nd} /{ }^{144} \mathrm{Nd},{ }^{206} \mathrm{~Pb} /{ }^{204} \mathrm{~Pb}$, and ${ }^{87} \mathrm{Sr} /{ }^{86} \mathrm{Sr}$ ratios on the $\mathrm{x}, \mathrm{y}$, and $\mathrm{z}$ axes, respectively. Symbols are similar to those defined in Figures 1-6; that is, bluish symbols are used for Atlantic, Pacific, and Indian MORB, red symbols are used for HIMU OIB (dark red CookAustral HIMU, light red St. Helena HIMU), green symbols are used for FOZO-like OIB, and gray symbols are used for the remaining OIB. The large green dot is the average of all FOZO-type OIB and is shown simply as a visual aid to follow FOZO-type compositions in the animated version of Figure 7 (Animation 1).

[e.g., Mahoney et al., 1989; Milner and LeRoex, 1996], or lower continental crust [Escrig et al., 2004; Hanan et al., 2004]. Nevertheless, FOZO appears to be one of the end-members or mixing components of the Indian MORB array as well.

[12] The FOZO end of the MORB array also overlaps with the radiogenic $\mathrm{Pb}$ isotope ratio end of many OIB arrays from a number of ocean islands, for example the Marquesas, Cape Verdes, Canary islands, Comores, Madeira and, by definition, some of the Cook-Austral islands (Figures 16). FOZO is therefore a component that is present not only in many MORB but also in many OIB sources. Consequently, OIB can be classified into HIMU-type OIB and basalts from islands that form mixing arrays originating from the MORB-FOZO array and diverging toward various isotopically "enriched" compositions such as EM 1 and EM 2 [Zindler and Hart, 1986] (Figure 1). It appears therefore that MORB-FOZO mixing is a virtually ubiquitous feature of both the MORB and OIB mantle, and that further isotopic variation imposed by the addition of enriched materials (EM-type) to these mixtures occurs in many, but not all, MORB and OIB (Figures 1-6) [Stracke et al., 2003b]. In contrast, HIMU-type OIB appear to be a special group of OIB, which only occur at two intraoceanic localities, St. Helena in the Atlantic Ocean and the Cook-Austral island chain in the South Pacific Ocean. These MORB and OIB isotope systematics, derived from the analysis of two-dimensional isotope ratio diagrams, are confirmed by extending this type of analysis to three-dimensions (see plot of ${ }^{143} \mathrm{Nd} /{ }^{144} \mathrm{Nd}$ versus ${ }^{206} \mathrm{~Pb} /{ }^{204} \mathrm{~Pb}$ and ${ }^{87} \mathrm{Sr} /{ }^{86} \mathrm{Sr}$ in Figure 7 and Animation 1).

[13] In summary, FOZO, as redefined here, is likely to be a ubiquitous component in the sources of MORB and OIB. The redefined composition of FOZO has the advantage that FOZO is actually observed in both MORB and OIB sources, and that 
much of the isotopic variability in both MORB and OIB can be explained with the fewest number of mantle components, that is, depleted MORB mantle (DMM), HIMU, two enriched mantle varieties (EM-1 and EM-2) [Zindler and Hart, 1986], and FOZO, as redefined in this study.

\section{FOZO and the Mantle Zoo}

[14] Other previously proposed common or ubiquitous components in MORB or OIB sources are "PREMA" (PREvalent Mantle) [Wörner et al., 1986; Zindler and Hart, 1986], "PHEM" (Primitive HElium Mantle) [Farley et al., 1992], and "C" (common component; [Hanan and Graham, 1996]. "PREMA" has a fairly depleted composition, originally defined to coincide with the depleted end of continental basalt arrays [Wörner et al., 1986; Zindler and Hart, 1986], and is not a suitable end-member for most MORB and OIB arrays $\left({ }^{87} \mathrm{Sr} /{ }^{86} \mathrm{Sr} \sim 0.7035,{ }^{143} \mathrm{Nd} /{ }^{144} \mathrm{Nd} \sim 0.5130\right.$, $\left.{ }^{206} \mathrm{~Pb} /{ }^{204} \mathrm{~Pb} \sim 18.3\right)$. The observation that the highest ${ }^{3} \mathrm{He} /{ }^{4} \mathrm{He}$ isotope ratios in OIB tend to occur preferentially in OIB with near bulk-Earth $\mathrm{Sr}$ and $\mathrm{Nd}\left({ }^{87} \mathrm{Sr} /{ }^{86} \mathrm{Sr}=0.7042-0.7052,{ }^{143} \mathrm{Nd} /{ }^{144} \mathrm{Nd}=\right.$ $0.51265-0.51280)$ and moderately radiogenic $\mathrm{Pb}$ isotope ratios $\left({ }^{206} \mathrm{~Pb} /{ }^{204} \mathrm{~Pb} \sim 18.5-19.0\right)$ has led to the postulation of "PHEM" as a common high ${ }^{3} \mathrm{He} /{ }^{4} \mathrm{He}$ ratio mantle component [Farley et al., 1992] (based mostly on data from the Samoan islands). The common component " $\mathrm{C}$ " $\left({ }^{87} \mathrm{Sr} /{ }^{86} \mathrm{Sr}=\right.$ $0.703-0.704,{ }^{143} \mathrm{Nd} /{ }^{144} \mathrm{Nd}=0.51285-0.51295$, ${ }^{206} \mathrm{~Pb} /{ }^{204} \mathrm{~Pb}=19.2-19.8,{ }^{207} \mathrm{~Pb} /{ }^{204} \mathrm{~Pb}=15.55-$ $\left.15.65,{ }^{208} \mathrm{~Pb} /{ }^{204} \mathrm{~Pb}=38.8-39.6\right)$ has been defined on the basis of the convergence of MORB Pb isotope arrays [Hanan and Graham, 1996], but is virtually identical to the previously defined composition of FOZO (see above) [Hart et al., 1992; Hauri et al., 1994], which was based on the apparent convergence of OIB Sr-Nd-Pb isotope arrays. "C" and the original composition of FOZO [Hart et al., 1992; Hauri et al., 1994] have similar isotopic composition and were inferred to represent a large part of or the entire lower mantle. They thus represent different manifestations of essentially the same concept. Note that several OIB arrays cross-cut these "C"-like compositions and an additional component with more radiogenic $\mathrm{Pb}$ isotope composition similar to the redefined composition of FOZO must be invoked to account for their total isotopic variability. In contrast, using the redefined composition of FOZO, depleted MORB mantle (DMM), HIMU, and a minimum of two different enriched mantle components (EM 1 and
EM 2 [Zindler and Hart, 1986]) explains the MORB and OIB isotope systematics with a minimum number of components and a maximum degree of simplicity.

\section{Possible Origin of HIMU and FOZO Signatures}

\subsection{Possible Origin of HIMU}

[15] Both the HIMU and the FOZO components are clearly not primordial but have been chemically fractionated in different ways. The HIMU component has a composition that is distinct from those of other OIB, including FOZO, by having higher ${ }^{206} \mathrm{~Pb} /{ }^{204} \mathrm{~Pb}$, but lower ${ }^{208} \mathrm{~Pb} /{ }^{206} \mathrm{~Pb}$ and ${ }^{208} \mathrm{~Pb} * / 206 \mathrm{~Pb} *$ ratios, as well as lower ${ }^{176} \mathrm{Hf} /{ }^{177} \mathrm{Hf}$ and ${ }^{87} \mathrm{Sr} /{ }^{86} \mathrm{Sr}$ ratios for given ${ }^{143} \mathrm{Nd} /{ }^{144} \mathrm{Nd}$ ratios (see Figures 1-7). The low ${ }^{208} \mathrm{~Pb}^{*}{ }^{206} \mathrm{~Pb}^{*}$ ratios of HIMU, which are similar to those of MORB, require a history of low time-integrated $\mathrm{Th} / \mathrm{U}$ ratios, but the high ${ }^{206} \mathrm{~Pb} /{ }^{204} \mathrm{~Pb}$ and ${ }^{208} \mathrm{~Pb} /{ }^{204} \mathrm{~Pb}$ ratios require high time-integrated $\mathrm{U} / \mathrm{Pb}$ and $\mathrm{Th} / \mathrm{Pb}$ ratios, unlike those of any other MORB and OIB sources (Figures 1-7). Overall, ${ }^{87} \mathrm{Sr} /{ }^{86} \mathrm{Sr}$ ratios of HIMU basalts are relatively low and show little variation compared to other isotope ratios $(\mathrm{Nd}, \mathrm{Hf}$, $\mathrm{Pb}$ ) and so require sources with either similarly low $\mathrm{Rb} / \mathrm{Sr}$ and similar age or, more likely, $\mathrm{Rb} / \mathrm{Sr}$ ratios of essentially zero to prevent significant ingrowth of ${ }^{87} \mathrm{Sr}$. This is supported by lower and relatively constant $\mathrm{Rb} / \mathrm{Sr}$ ratios in HIMU basalts compared to other OIB. At the same time, considerable variations in $\mathrm{Pb}$, but also $\mathrm{Hf}$ and $\mathrm{Nd}$ isotope ratios require sources with variable time-integrated $\mathrm{U} / \mathrm{Pb}$, $\mathrm{Th} / \mathrm{Pb}, \mathrm{Th} / \mathrm{U}$, and to a lesser degree, $\mathrm{Sm} / \mathrm{Nd}$ and $\mathrm{Lu} / \mathrm{Hf}$ ratios. Thus the HIMU source is distinct from those of other OIB sources by having lower time-integrated $\mathrm{Th} / \mathrm{U}$ and $\mathrm{Rb} / \mathrm{Sr}$, but higher $\mathrm{U} / \mathrm{Pb}$ and $\mathrm{Th} / \mathrm{Pb}$ ratios.

[16] These characteristics of the HIMU source have most often been explained as a result of recycled oceanic crust being, or at least being a significant part of the HIMU source [e.g., Hofmann and White, 1982; Vidal et al., 1984; Palacz and Saunders, 1986; Zindler and Hart, 1986; Halliday et al., 1988; Hart, 1988; Nakamura and Tatsumoto, 1988; Weaver, 1991; Chauvel et al., 1992; Hauri and Hart, 1993; Reisberg et al., 1993; Roy-Barman and Allègre, 1995; Hauri et al., 1996; Chauvel et al., 1997; Hofmann, 1997; Lassiter and Hauri, 1998; Salters and White, 1998]. While the Nd and $\mathrm{Hf}$ isotopic signatures are compatible with ancient mantle-derived melts created in the garnet-stability 


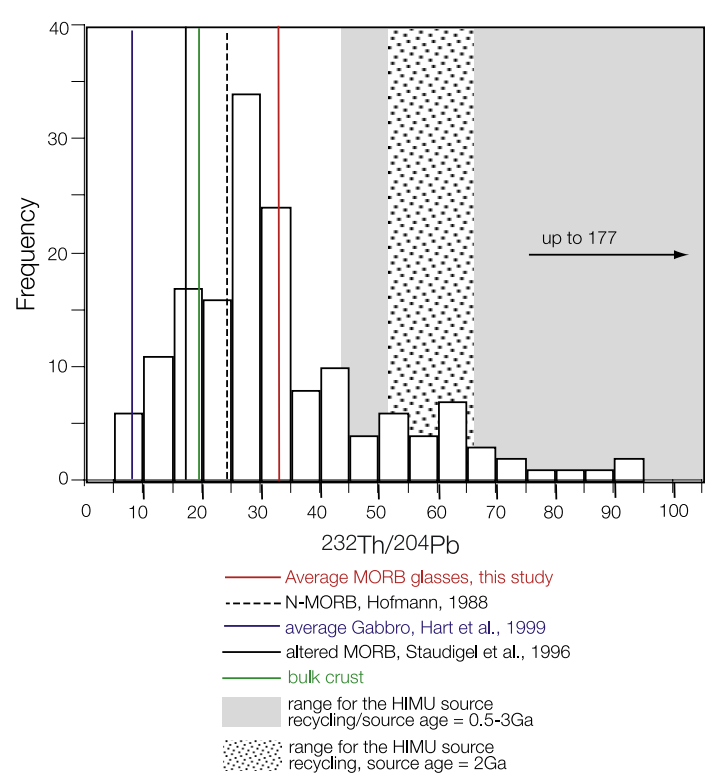

Figure 8. Histogram showing the variation and frequency of ${ }^{232} \mathrm{Th} /{ }^{204} \mathrm{~Pb}$ ratios in present-day MORB glasses (data can be obtained from Stracke et al. [2003a]) compared to the range of ${ }^{232} \mathrm{Th} /{ }^{204} \mathrm{~Pb}$ ratios calculated for the HIMU source (gray field). Calculations assume a range of recycling ages of 3-0.5 Ga. The stippled field is the required range of ${ }^{232} \mathrm{Th} /{ }^{204} \mathrm{~Pb}$ ratios for a 2 Gyr old HIMU source. Also shown are the average of the compiled ratios (average MORB), as well as the average N-MORB of Hofmann [1988], altered MORB [Staudigel et al., 1996], gabbro [Hart et al., 1999], and an estimate for a bulk igneous crust consisting of fresh MORB, altered MORB, and gabbro (see Stracke et al. [2003a] for details and further discussion).

field [e.g., Salters and White, 1998], peridotite melting cannot at the same time create the very low $\mathrm{Rb} / \mathrm{Sr}$ ratios, unless relatively large degrees of melting and/or an extremely depleted peridotite is assumed. Large degrees of peridotite melting also lead to relatively little fractionation of the $(\mathrm{U}$, $\mathrm{Th} / \mathrm{Pb}$ and $\mathrm{Th} / \mathrm{U}$ ratios. Therefore, although the Lu-Hf and Sm-Nd characteristics of the HIMU source component are compatible with mantlederived melts, the $\mathrm{Rb}-\mathrm{Sr}$ and U-Th-Pb systematics cannot be explained by this same process. It follows that the HIMU source is unlikely to be similar to unmodified mantle-derived melts. This is confirmed by comparing parent-daughter ratios in global MORB and suitable parent-daughter ratios of the HIMU source for a range of possible ages of the HIMU source [e.g., Hauri and Hart, 1993; Stracke et al., 2003a] (Figure 8). Hofmann and White [1980, 1982] suggested that hydrothermally altered oceanic crust is a suitable source for
HIMU basalts, but the increase in alkali elements and $\mathrm{U}$ in altered oceanic crust [e.g., Staudigel et al., 1995, 1996; Kelley et al., 2003] leads to very high $\mathrm{Rb} / \mathrm{Sr}$ and $\mathrm{U} / \mathrm{Pb}$ ratios which are unsuitable for HIMU sources [e.g., Hart and Staudigel, 1989; Chauvel et al., 1992; Rehkämper and Hofmann, 1997; Stracke et al., 2003a]. Oceanic gabbros are characterized by low $\mathrm{Rb} / \mathrm{Sr}$ ratios [e.g., Zimmer et al., 1995; Hart et al., 1999], but have $\mathrm{U} / \mathrm{Pb}$ and $\mathrm{Th} / \mathrm{Pb}$ ratios that are too low for HIMU sources [Hart et al., 1999; Stracke et al., 2003a]. In fact, fresh MORB, altered MORB and oceanic gabbros all have $\mathrm{Th} / \mathrm{Pb}$ ratios which are too low compared to HIMU sources (with an age of $3-0.5 \mathrm{Ga}$ ), so that even a complete section of oceanic crust (altered MORB + MORB + gabbros) cannot be a suitable HIMU source [Stracke et al., 2003a]. Subduction modification leads to substantial $\mathrm{Pb}$ loss compared to both $\mathrm{U}$ and $\mathrm{Th}$ and to preferential leaching of $\mathrm{U}$ compared to Th [see Stracke et al., 2003a, and references therein]. Whether or not subductionmodified oceanic crust can be a suitable HIMU source, however, is dependent on the interplay of a number of hard-to-constrain parameters, such as the bulk composition of the oceanic crust before subduction, its age, and the mode of modification during subduction and storage in the mantle [Stracke et al., 2003a].

[17] Oceanic crust has a wide range of compositions, especially when considering the fact that the extent and mode of hydrothermal alteration and the proportion and composition of different parts of the oceanic crust (altered MORB, fresh MORB, gabbros) can be quite variable. On the basis of the $\mathrm{Pb}$ isotope systematics of HIMU basalts, Hauri and Hart [1993] argued that recycling ages are likely to be between 2.1 and $0.7 \mathrm{Ga}$, but an even larger range of possible recycling ages cannot be excluded at this point. Perhaps the greatest uncertainty in evaluating the potential of ancient recycled crust as a possible HIMU source, however, is the mode and extent of modification during subduction. Although experimental studies of element transfer during sub-arc processing agree in most cases on the relative fractionation of elements, the magnitude of fractionation remains uncertain. Thus it remains plausible to assume a large range of values for all relevant parameters (age, composition before and after subduction-processing) and a range of isotopic compositions for the present-day isotopic composition of the recycled crust, both within and outside the field for HIMU basalts result. Until more precise constraints on 
the critical parameters become available, considerable ambiguity remains attached to the notion that ancient subduction-modified oceanic crust is a suitable HIMU source [e.g., Stracke et al., 2003a].

[18] Alternative ways proposed to explain the origin of the HIMU source are sparse and are predominantly related to metasomatic (i.e., meltrock interaction) processes in the suboceanic or subcontinental lithospheric mantle (see, for example, discussions by Hart et al. [1986], Sun and McDonough [1989], and Niu and O'Hara [2003]). Despite the numerous studies of such processes, our understanding of the chemical composition of potential metasomatic agents and metasomatized materials, the scale of such processes and the ways by which metasomatized material may end up as source material for OIB remains limited and is characterized by uncertainties probably similar to or even exceeding those related to recycling of subduction-modified oceanic crust. Only for the case of generating EM-2 signatures in Samoan basalts has a well-constrained metasomatic model been advanced [Workman et al., 2004].

\subsection{Possible Origin of FOZO}

[19] FOZO differs from HIMU in having lower ${ }_{206,207,208} \mathrm{~Pb} /{ }^{204} \mathrm{~Pb}$, but higher ${ }^{208} \mathrm{~Pb} /{ }^{206} \mathrm{~Pb}$ and ${ }^{208} \mathrm{~Pb} * / 206 \mathrm{~Pb}^{*}$ ratios. ${ }^{87} \mathrm{Sr} /{ }^{86} \mathrm{Sr}$ ratios in $\mathrm{FOZO}$ basalts are higher than in HIMU basalts and are positively correlated with ${ }^{206,207,208} \mathrm{~Pb} /{ }^{204} \mathrm{~Pb}$ ratios. There are too few Hf isotope data to allow a comparison of FOZO and HIMU basalts. FOZO basalts extend the MORB trend in Figure 1. In contrast to HIMU sources, variations in $\mathrm{U} / \mathrm{Pb}(\mathrm{Th} /$ $\mathrm{Pb}, \mathrm{Th} / \mathrm{U}$ ) ratios in FOZO sources are therefore coupled to variations in $\mathrm{Rb} / \mathrm{Sr}$ ratios. Clearly, FOZO and HIMU basalts have different sources, but do they need to have sources with an entirely different origin? In other words, can HIMU and FOZO signatures both be explained by recycling of oceanic crust?

[20] This question is difficult to answer for a variety of reasons. Principally, for the subduction and recycling process, the same arguments hold as presented in the discussion above. Among the most important arguments to consider is that most $\mathrm{Th} / \mathrm{Pb}$ ratios in fresh MORB, altered MORB and gabbros are also too low to produce the most radiogenic $\mathrm{Pb}$ isotope signatures in FOZO sources. For FOZOtype signatures along the MORB-FOZO-array with less radiogenic $\mathrm{Pb}$ isotope signatures, however, $\mathrm{Th} / \mathrm{Pb}$ isotope ratios on the high side of those found in present-day MORB (Figures 1-7) can be sufficient. Increasing the $(\mathrm{U}, \mathrm{Th}) / \mathrm{Pb}$ ratios during subduction is therefore also required to produce the most radiogenic FOZO signatures, but may not be strictly required for FOZO-type signatures along the MORB-FOZO array with less radiogenic $\mathrm{Pb}$ isotope ratios. In order to better evaluate the necessity for, or the extent of subduction-modification for FOZO compared to HIMU sources (assuming that both originate from recycled oceanic crust), the principal questions to answer are as follows: Can recycling of oceanic crust produce isotope systematics similar to those characteristic of FOZO? Is it possible that different extents or different mechanisms of subductionmodification lead to the extremely low $\mathrm{Rb} / \mathrm{Sr}$ and high $(\mathrm{U}, \mathrm{Th}) / \mathrm{Pb}$ ratios in case of the HIMU source and to the coupled changes in $\mathrm{Rb} / \mathrm{Sr}$ and $(\mathrm{U}, \mathrm{Th}) / \mathrm{Pb}$ ratios required for the FOZO sources? In order to answer this question, a number of other open questions relating to sub-arc modification mechanisms have to be answered first. For example, how variable is the overall composition of the subducted oceanic crust, both before and after subduction? What parameters influence both the absolute flux of the elements as well as the flux of one element relative to another? How variable are these parameters in different subduction zone settings and which processes are responsible for potential differences? Are potential changes in the relative fractionation of the elements during sub-arc modification between different subduction zones and/or through time large enough to cause differences in isotopic composition of ancient sub-arc modified crust?

[21] Combined isotopic and trace element data on FOZO and HIMU basalts may provide more information about the difference between the FOZO and HIMU sources. Given the limited amount of highquality data available, however, the trace element systematics of FOZO and HIMU basalts are difficult to evaluate. Many FOZO-type OIB have rather similar trace element composition compared to HIMU basalts, which would argue in favor of a common origin of the FOZO and HIMU sources. There are, however, some differences between FOZO and HIMU basalts erupted on the island of Rurutu of the Cook-Austral chain. FOZO and HIMU basalts on Rurutu were erupted during different phases of volcanism. Chauvel et al. [1997] showed that young Rurutu lavas (FOZO) are isotopically more depleted and characterized by different trace element ratios and concentrations compared to old Rurutu lavas (HIMU; e.g., 
different $\mathrm{La} / \mathrm{Yb}, \mathrm{Ce} / \mathrm{Pb}, \mathrm{Ba} / \mathrm{Nb}, \mathrm{Zr} / \mathrm{Hf}$ ). Due to the considerable scatter observed in the literature data from other FOZO-type basalts from the CookAustral islands, however [e.g., Palacz and Saunders, 1986; Dupuy et al., 1988, 1989; Nakamura and Tatsumoto, 1988; Chaffey et al., 1989; Chauvel et al., 1992; Hemond et al., 1994; Woodhead, 1996; Kogiso et al., 1997; Dostal et al., 1998], it remains unclear whether these differences between young and old Rurutu lavas (FOZO versus HIMU) are a general feature of FOZO and HIMU basalts, or are a specific characteristic of Rurutu lavas only.

\section{Role of HIMU and FOZO in the Mantle}

[22] HIMU is apparently absent in MORB and rare in OIB. In fact, it has been documented at only two intraoceanic hot spots; St. Helena in the Atlantic Ocean and the Cook-Austral island chain in the South Pacific Ocean. Attributing HIMU signatures to ancient recycled oceanic crust requires a very specific combination of age and composition of the recycled crust (see above). Therefore one single event, rather than continuous subduction and recycling of oceanic crust into the Earth's mantle, would have to be invoked to attribute HIMU signatures to ancient recycled oceanic crust, consistent with its rarity among OIB. Taking into account that there are slight differences between the St. Helena and the Cook-Austral HIMU basalts (mainly for $\mathrm{Pb}$ isotope ratios) and that the isotopic composition of the HIMU source might range to more extreme values than those observed in the basalts, these constraints may be somewhat relaxed and a slightly larger number of different recycling ages and/or compositions may be allowed [Stracke et al., 2003a].

[23] In contrast to HIMU, FOZO appears to be a ubiquitous component in both the MORB and OIB mantle sources. Christensen and Hofmann [1994] argued that the origin of HIMU-type sources in general (i.e., FOZO and HIMU) is most plausibly explained by processes of continuous oceanic differentiation, recycling and remixing. These authors showed that nearly linear arrays of MORB and OIB (including FOZO and HIMU) in ${ }^{207} \mathrm{~Pb} /{ }^{204} \mathrm{~Pb}-$ ${ }^{206} \mathrm{~Pb} / 204 \mathrm{~Pb}$ and ${ }^{206} \mathrm{~Pb} /{ }^{204} \mathrm{~Pb}-{ }^{143} \mathrm{Nd} /{ }^{144} \mathrm{Nd}$ diagrams could be generated by segregating and temporarily storing a portion of the subducted oceanic crust at the base of the convecting system, and they showed that the calculated compositions are in reasonable agreement with the observed MORB and HIMU-type OIB data. In their calculation, Christensen and Hofmann [1994] assumed partition coefficients for the relevant elements $(\mathrm{U}, \mathrm{Pb}, \mathrm{Rb}, \mathrm{Sr}$, $\mathrm{Sm}, \mathrm{Nd}$ ) during ocean-crust formation. In the following we will test this model of producing a range of signatures similar to FOZO by continuously recycling oceanic crust by using measured MORB compositions and by asking a slightly different question (see section 5.2): Are the chemical parent-daughter and $\mathrm{Sr}, \mathrm{Nd}$ and $\mathrm{Pb}$ isotope ratios measured in present-day MORB appropriate for producing MORB-FOZO-like isotope arrays in the future?

[24] $\mathrm{Rb} / \mathrm{Sr}$ versus $\mathrm{Sm} / \mathrm{Nd}$ ratios in present-day MORB are shown in Figure 9. The data set used in Figure 9 is the compilation of $S u$ [2002] because it provides global ridge segment-by-ridge segment MORB averages which appear to be particularly useful for our purpose. There is a significant negative correlation between these parent-daughter ratios $(\mathrm{Rb} / \mathrm{Sr}$ and $\mathrm{Sm} / \mathrm{Nd})$ in present-day MORB (Figure 9a). In addition, Figure 9b shows the calculated isotopic compositions of this array $1 \mathrm{Gyr}$ from now, using the average present-day $\mathrm{Sr}$ and $\mathrm{Nd}$ isotope ratios of each ridge segment as initial isotopic composition [Su, 2002]. The resulting future isotope array has the expected negative slope and correlation, with only slightly shallower slope compared to the array observed in presentday MORB. A similar exercise is presented in Figure 10 for $\mathrm{U} / \mathrm{Pb}$ and $\mathrm{Sm} / \mathrm{Nd}$ ratios. The compilation of $\mathrm{Su}[\mathrm{Su}, 2002]$ does not provide $\mathrm{U} / \mathrm{Pb}$ ratios, so we have augmented an existing compilation taken from the PetDB database [Hofmann, 2003] by recent publications not yet covered by PetDB (e.g., Le Roux et al. [2002] for the South Atlantic, Mahoney et al. [2002] and unpublished data by Nauret [2004] for the Indian Ocean). This data set with more than 500 samples shows a negative correlation between $\mathrm{U} / \mathrm{Pb}$ and $\mathrm{Sm} / \mathrm{Nd}$ ratios in all three major ocean basins, including the Indian Ocean, which is remarkable because ${ }^{206} \mathrm{~Pb} /{ }^{204} \mathrm{~Pb}$ and ${ }^{143} \mathrm{Nd} /{ }^{144} \mathrm{Nd}$ ratios for MORB from the Atlantic and Pacific ocean basins are also negatively correlated, but those from the Indian Ocean are not (Figure 10b). This observation is consistent with the interpretation that the isotope correlations in Atlantic and Pacific MORB are well explained by continuous recycling of variably fractionated MORB, whereas the subIndian Ocean mantle is contaminated by some type of recycled continental material, which might be sedimentary, lithospheric, or lower crustal in nature [e.g., Mahoney et al., 1989; Milner and 

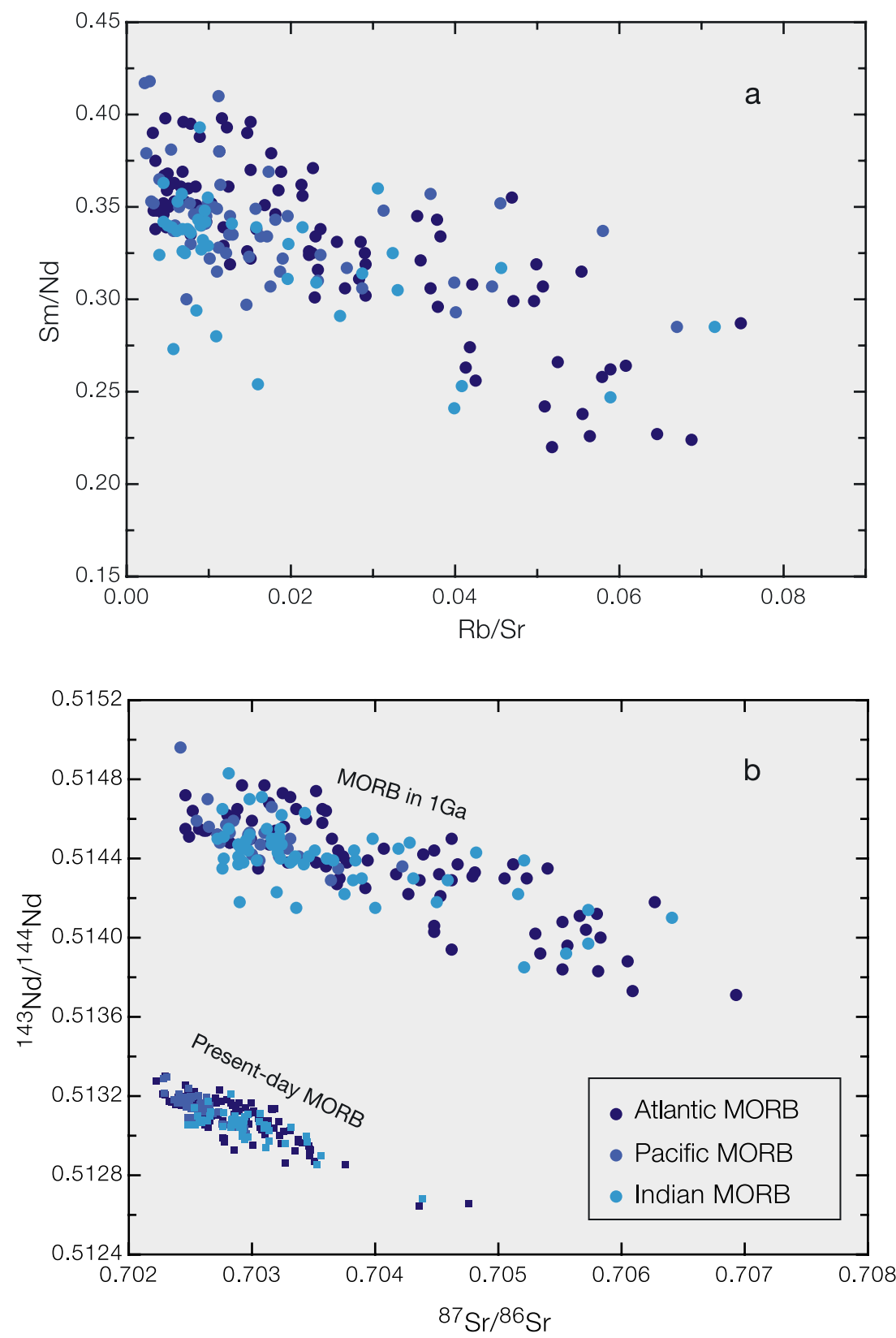

Figure 9. (a) Plot of $\mathrm{Rb} / \mathrm{Sr}$ versus $\mathrm{Sm} / \mathrm{Nd}$ ratios in present-day MORB. (b) Diagram showing the ${ }^{87} \mathrm{Sr} /{ }^{86} \mathrm{Sr}$ versus ${ }^{143} \mathrm{Nd} /{ }^{144} \mathrm{Nd}$ relationship in present-day MORB and their calculated isotopic composition $1 \mathrm{Gyr}$ from now. Upon aging the inverse relationship between $\mathrm{Rb} / \mathrm{Sr}$ and $\mathrm{Sm} / \mathrm{Nd}$ ratios (Figure 9a) translates into a negative correlation between ${ }^{87} \mathrm{Sr} /{ }^{86} \mathrm{Sr}$ and ${ }^{143} \mathrm{Nd} /{ }^{144} \mathrm{Nd}$ ratios with only slightly shallower slope compared to present-day MORB. The average $\mathrm{Sr}$ and $\mathrm{Nd}$ isotope composition for each ridge segment is used as initial isotopic composition. A similar array would be obtained by assuming the same initial isotopic composition for all samples. The data set used is the global ridge segment-by-ridge segment average MORB compiled by Su [2002], which provides $\mathrm{Rb}, \mathrm{Sr}$, Sm, and Nd concentrations and $\mathrm{Sr}$ and $\mathrm{Nd}$ isotope compositions on the same samples.

LeRoex, 1996; Rehkämper and Hofmann, 1997; Escrig et al., 2004; Hanan et al., 2004].

[25] The discussion above shows that MORBFOZO-like isotope arrays can, in principle, be produced by continuously recycling oceanic crust without the requirement of substantial chemical modification during subduction of the oceanic crust, in marked contrast to HIMU signatures. This would account for the time-integrated evolution with positively correlated $\mathrm{Rb} / \mathrm{Sr}$ and $\mathrm{U} / \mathrm{Pb}$ ratios required for FOZO, since during generation of the oceanic crust, both $\mathrm{Rb}$ and $\mathrm{U}$ are expected to be significantly more incompatible than $\mathrm{Sr}$ and $\mathrm{Pb}$, 

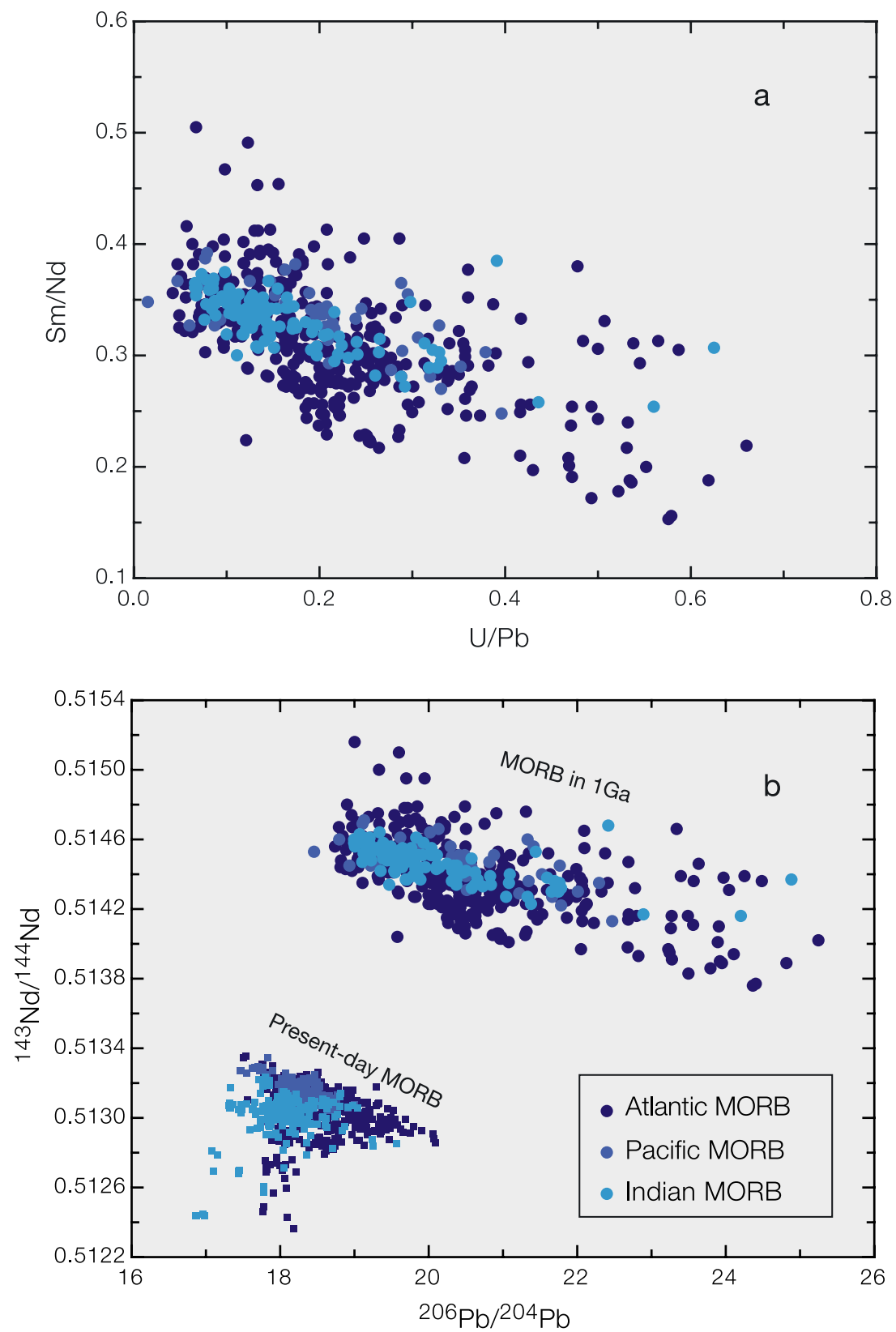

Figure 10. (a) Plot of $\mathrm{U} / \mathrm{Pb}$ versus $\mathrm{Sm} / \mathrm{Nd}$ ratios in present-day MORB. The data set used is the MORB compilation by Hofmann [2003] augmented by data from Le Roux et al. [2002] for the South Atlantic and Mahoney et al. [2002] and unpublished data by Nauret [2004] for the Indian Ocean. (b) Diagram showing the ${ }^{206} \mathrm{~Pb} /{ }^{204} \mathrm{~Pb}$ versus ${ }^{143} \mathrm{Nd} /{ }^{144} \mathrm{Nd}$ relationship in present-day MORB and their calculated isotopic composition 1 Gyr from now. Upon aging the inverse relationship between $\mathrm{U} / \mathrm{Pb}$ and $\mathrm{Sm} / \mathrm{Nd}$ ratios (Figure 10a) translates into a negative correlation between ${ }^{206} \mathrm{~Pb} /{ }^{204} \mathrm{~Pb}$ and ${ }^{143} \mathrm{Nd} /{ }^{144} \mathrm{Nd}$ ratios similar to those of present-day MORB. U, Pb, Sm, and Nd concentration data are from the data set used in Figure 9a. For lack of $\mathrm{Pb}$ and $\mathrm{Nd}$ isotope data on the same samples, an initial isotopic composition of ${ }^{206} \mathrm{~Pb} /{ }^{204} \mathrm{~Pb}=18.3$ and ${ }^{143} \mathrm{Nd} /{ }^{144} \mathrm{Nd}=0.51315$ is assumed. MORB isotope data for presentday MORB are from the compilation provided by Stracke et al. [2003a].

respectively [see, e.g., Hofmann, 1988]. As discussed above, $\mathrm{Th} / \mathrm{Pb}$ ratios in the oceanic crust are, however, too low to account for the most radiogenic $\mathrm{Pb}$ isotope signatures along the MORBFOZO array and would require either unusually enriched ancient MORB or some $\mathrm{Pb}$ extraction during subduction to produce the appropriate $\mathrm{Th} / \mathrm{Pb}$ ratios in the recycled crust. If, despite this caveat, the notion is accepted that FOZO can be produced continuously by recycling oceanic crust, it follows that FOZO is not one single mixing component but is simply the most radiogenic 
end-member from a family of products with variable isotopic signatures which plot along the MORB-FOZO array in Figures 1-7.

[26] Judging from the apparent ubiquity of FOZO in MORB and OIB sources (see discussion above), FOZO is expected to reside in possibly the entire mantle. A similar model has previously been suggested by Hart et al. [1992] as one possible model to explain the convergence of OIB arrays toward compositions in between depleted MORB and HIMU (with a ubiquitous HIMU-like component that is restricted to the upper mantle). The apparent heterogeneity of the MORB source (upper mantle), which has become obvious from the large numbers of isotopic analyses of MORB (see, e.g., discussions by Hofmann [2003] and Salters and Stracke [2004]), is in good agreement with this observation. Furthermore, increasing viscosity with increasing depth makes effective homogenization in the deeper mantle more difficult than in the upper mantle. If recycled material, which may originate in a number of ways, makes its way into the lower mantle as would appear likely from recent seismic tomography studies [e.g., Grand et al., 1997; van der Hilst et al., 1997], it appears unlikely that the lower mantle either remained compositionally homogeneous due to long-term isolation, or that introduced compositional heterogeneities became effectively homogenized in the lower mantle. These arguments support the notion of a compositionally heterogeneous lower mantle and are in good agreement with the dispersal of FOZO in the entire mantle.

[27] On the basis of the above discussion, FOZO is likely to be a ubiquitously dispersed, small-scale component in possibly the entire mantle. Recycling of oceanic lithosphere is currently the only process that is known to have transported significant amounts of chemically distinct materials into the mantle over geological timescales $(0-4.5 \mathrm{Ga})$. The apparent ubiquity of FOZO in MORB and OIB sources and the fact that the calculated isotopic composition of recycled MORB can yield arrays similar to the MORB-FOZO arrays (see discussion above and Figures 9 and 10) suggest an origin by recycling of oceanic crust for FOZO. Alternatively, some other large-scale ubiquitous, but in its importance yet neglected process might be invoked. Possible candidates are delamination of the lithospheric mantle [McKenzie and O'Nions, 1983, 1995] and melt-rock interaction in the suboceanic mantle [e.g., Zindler et al., 1979; Richardson et al., 1982; Hart et al., 1986; Sun and McDonough,
1989; Niu and O'Hara, 2003; Workman et al., 2004].

\section{FOZO as a "Young HIMU" Source?}

[28] Vidal [1992] and Thirlwall [1995, 1997] previously suggested that variably radiogenic lead in OIB can originate from continuously producing high- $\mu$ materials, resulting in a range of sources with progressively less extreme $\mathrm{Pb}$ isotope signatures with decreasing age. Especially some OIB signatures with ${ }^{206} \mathrm{~Pb} / 204 \mathrm{~Pb}$ ratios between 19 and 20 were attributed by Vidal [1992] and Thirlwall $[1995,1997]$ to so-called "young HIMU" sources with ages less than $1 \mathrm{Ga}$. FOZO, as redefined here, is a ubiquitous component in the sources of MORB and OIB, which is produced continuously by recycling oceanic crust. FOZO has therefore, at first sight, some resemblance with these "young HIMU" components. However, FOZO is defined by compositions that overlap and extend the trend of MORB in a ${ }^{206} \mathrm{~Pb} /{ }^{204} \mathrm{~Pb}$ or ${ }^{208} \mathrm{~Pb} /{ }^{206} \mathrm{~Pb}$ versus ${ }^{87} \mathrm{Sr} /{ }^{86} \mathrm{Sr}$ diagram (see discussion above and Figure 1), whereas the "young HIMU" by Vidal [1992] and Thirlwall [1995, 1997] are defined solely by having negative $\Delta 7 / 4$ values $\left(\Delta 7 / 4\right.$ is the vertical deviation of the ${ }^{207} \mathrm{~Pb} /{ }^{204} \mathrm{~Pb}$ ratios from a "Northern Hemisphere Reference Line (NHRL)" defined by Hart [1984] in a ${ }^{206} \mathrm{~Pb} /{ }^{204} \mathrm{~Pb}-{ }^{207} \mathrm{~Pb} /{ }^{204} \mathrm{~Pb}$ diagram). In addition, "young HIMU" are expected to be similar in chemistry to St. Helena and Cook-Austral-type HIMU, and should thus be characterized by a similar decoupling of the time-integrated $\mathrm{Rb} / \mathrm{Sr}$ and $\mathrm{U} / \mathrm{Pb}$ and thus ${ }^{87} \mathrm{Sr} /{ }^{86} \mathrm{Sr}$ and ${ }^{206} \mathrm{~Pb} /{ }^{204} \mathrm{~Pb}$ ratios. In contrast, the time-integrated evolution of $\mathrm{Rb} / \mathrm{Sr}$ and $\mathrm{U} / \mathrm{Pb}$ in FOZO is, by definition, positively coupled, resulting in increasing ${ }^{87} \mathrm{Sr} /{ }^{86} \mathrm{Sr}$ with increasing ${ }^{206} \mathrm{~Pb} / 204 \mathrm{~Pb}$ ratios. Another fundamental difference between the FOZO concept developed here and the "young HIMU" model is that isotopic differences in such "young HIMU" sources are expected to arise from differences in age of chemically similar components, whereas the isotopic differences for FOZO are proposed to arise predominantly from variable enrichment in recycled products (see discussion above; Figures 9 and 10). Moreover, $\mathrm{Sr}$ and $\mathrm{Nd}$ isotope signatures for OIB with the most negative $\Delta 7 / 4$ are quite variable and can therefore not be derived from sources with coherent time-integrated chemical evolution. The negative $\Delta 7 / 4$ in the OIB listed by Vidal [1992] and Thirlwall [1995, 1997] therefore do not derive from a similar source component, 
but are rather one similar feature of a number of different source components.

[29] In addition, the $\Delta 7 / 4$ values depend on the slope and intercept of the corresponding reference line. Taking errors for both slope and intercept into account, uncertainties of several $\Delta 7 / 4$ units result. Note that some of the islands that have originally been used to define the NHRL by Hart [1984] are the majority of those that define the negative $\Delta 7 / 4$ OIB (notably the Azores, Canary islands, Hawaii and Iceland). The significance of small deviations from the NHRL ( $\Delta 7 / 4$ up to \pm about 3$)$ is therefore not entirely clear.

[30] It follows from the discussion above that similarities in $\Delta 7 / 4$ values alone are not sufficient to define mantle components with similar timeintegrated chemical evolution (so-called "young HIMU" sources).

\section{Conclusions}

[31] Highly radiogenic $\mathrm{Pb}$ isotope signatures in MORB and OIB are caused by melting two different mantle sources: FOZO and HIMU. HIMU is the classical HIMU component and is restricted to two intraoceanic localities; St. Helena in the Atlantic Ocean and the Cook-Austral islands in the South Pacific Ocean. FOZO, as redefined here, is compositionally different and is a much more common and perhaps ubiquitous component in the MORB source. Many OIB overlap with FOZO and/or form isotope trends which diverge from the MORB-FOZO array toward various isotopically "enriched" compositions ("enriched mantle," EM [Zindler and Hart, 1986]). It appears therefore that FOZO is also a common component in many OIB sources, and may well be present in the entire mantle. HIMU on the other hand is clearly a rare component in the mantle and is not a common mixing end-member of other MORB and OIB arrays. The apparent ubiquity of FOZO in the mantle and the calculated isotopic evolution of compositionally diverse MORB suggest that normal mantle melting and continuous subduction and aging of that crust during recycling through the mantle are the dominant causes of the MORB-FOZO arrays. Addition of EM-type material can disturb or even destroy the dominant MORB-FOZO isotope correlation. This effect is particularly evident in Indian-Ocean MORB. In case an origin by ancient recycled oceanic crust is also postulated for HIMU, the production of HIMU has to be a special case of recycling oceanic crust, representing a rare combination of age and composition of the subduction-modified oceanic crust, consistent with its rarity among OIB. The redefinition of FOZO thus establishes a simple conceptual framework to explain the isotopic variability in both MORB and OIB with the fewest number of possible, and actually observed mantle components, by mixing between depleted MORB mantle (DMM), FOZO as redefined here, and a minimum of two different enriched mantle components (EM 1 and EM 2 [Zindler and Hart, 1986]). HIMU on the other hand, does not appear to contribute significantly to the isotope arrays found in MORB and other OIB, and may ultimately be derived from a single reservoir that is different from any other MORB or OIB component.

\section{Acknowledgments}

[32] A.S. thanks Alan Zindler for his groundbreaking work in interpreting isotope systematics in oceanic basalts. W. M. White and C. Chauvel are thanked for editorial handling and together with P. Janney and an anonymous journal reviewer for comments on the manuscript. M. Bizimis and M. Willbold are thanked for their comments on earlier versions of this manuscript. This work is partially supported by the Deutsche Forschungsgmeinschaft (DFG grant STR853/1 to A.S).

\section{References}

Allègre, C. J. (1969), Comportement des systemes U-Th-Pb dans le manteau superieur et modele d'evolution de ce dernier au cours des temps geologiques, Earth Planet. Sci. Lett., 5, 261-269.

Allègre, C. J., O. Brévart, B. Dupré, and J. F. Minster (1980), Isotopic and chemical effects produced in a continuously differentiating convecting Earth mantle, Philos. Trans. R. Soc. London, Ser. A, 297, 447-477.

Allègre, C. J., B. Hamelin, A. Provost, and B. Dupré (1987), Topology in isotopic multispace and origin of the mantle chemical heterogeneities, Earth Planet. Sci. Lett., 81, 319337.

Armstrong, R. L. (1968), A model for the evolution of strontium and lead isotopes in a dynamic Earth, Rev. Geophys., 6, $175-199$.

Chaffey, D. J., R. A. Cliff, and B. M. Wilson (1989), Characterization of the St. Helena magma source, in Magmatism in the Ocean Basins, vol. 42, edited by A. D. Saunders and M. J. Norry, Geol. Soc. Spec. Publ., 42, 257-276.

Chauvel, C., A. W. Hofmann, and P. Vidal (1992), HIMU-EM: The French-Polynesian Connection, Earth Planet. Sci. Lett., 110, 99-119.

Chauvel, C., S. J. Goldstein, and A. W. Hofmann (1995), Hydration and dehydration of oceanic crust controls $\mathrm{Pb}$ evolution of the mantle, Chem. Geol., 126, 65-75.

Chauvel, C., W. McDonough, G. Guille, R. Maury, and R. Duncan (1997), Contrasting old and young volcanism in Rurutu Island, Austral chain, Chem. Geol., 139, 125-143.

Christensen, U. R., and A. W. Hofmann (1994), Segregation of subducted oceanic crust in the convecting mantle, J. Geophys. Res., 99, 19,867-19,884. 
Dostal, J., B. Cousens, and C. Dupuy (1998), The incompatible element characteristics of an ancient subducted sedimentary component in ocean island basalts from French Polynesia, J. Petrol., 39, 937-952.

Dupuy, C., H. G. Barsczus, J. M. Liotard, and J. Dostal (1988), Trace element evidence for the origin of ocean island basalts: An example from the Austral Islands (French Polynesia), Contrib. Mineral. Petrol., 98, 293-302.

Dupuy, C., H. G. Barsczus, J. Dostal, P. Vidal, and J. M. Liotard (1989), Subducted and recycled lithosphere as the mantle source of ocean island basalts from southern Polynesia, central Pacific, Chem. Geol., 77, 1-18.

Elliott, T., A. Zindler, and B. Bourdon (1999), Exploring the Kappa Conundrum: The role of recycling in the lead isotope evolution of the mantle, Earth Planet. Sci. Lett., 169, 129145.

Escrig, S., F. Capmas, B. Dupré, and C. J. Allègre (2004), Osmium isotopic constraints on the nature of the DUPAL anomaly from Indian mid-ocean-ridge basalts, Nature, 431, $59-63$.

Farley, K. A., J. H. Natland, and H. Craig (1992), Binary mixing of enriched and undegassed (primitive?) mantle components $(\mathrm{He}, \mathrm{Sr}, \mathrm{Nd}, \mathrm{Pb})$ in Samoan lavas, Earth Planet. Sci. Lett., 111, 183-199.

Galer, S. J. G., and R. K. O'Nions (1985), Residence time of thorium, uranium and lead in the mantle with implications for mantle convection, Nature, 316, 778-782.

Gast, P. W. (1968), Trace element fractionation and the origin of tholeiitic and alkaline magma types, Geochim. Cosmochim. Acta, 32, 1057-1086.

Gast, P. W., G. R. Tilton, and C. Hedge (1964), Isotopic composition of lead and strontium from Ascension and Gough Islands, Science, 145, 1181-1185.

Grand, S. P., R. D. van der Hilst, and S. Widiyantoro (1997), Global seismic tomography: A snapshot of convection in the Earth, GSA Today, 7, 1-7.

Halliday, A. N., A. P. Dickin, A. E. Fallick, and J. G. Fitton (1988), Mantle dynamics: A Nd, Sr, Pb and O isotopic study of the Cameroon Line volcanic chain, J. Petrol., 29, 181211.

Hanan, B. B., and D. W. Graham (1996), Lead and helium isotope evidence from oceanic basalts for a common deep source of mantle plumes, Science, 272, 991-995.

Hanan, B. B., J. Blichert-Toft, D. G. Pyle, and D. M. Christie (2004), Contrasting origins of the upper mantle MORB source as revealed by $\mathrm{Hf}$ and $\mathrm{Pb}$ isotopes from the Australian-Antarctic discordance, Nature, 432, 91-94.

Hart, S. R. (1984), A large-scale isotope anomaly in the Southern Hemisphere mantle, Nature, 309, 753-757.

Hart, S. R. (1988), Heterogeneous mantle domains-Signatures, genesis and mixing chronologies, Earth Planet. Sci. Lett., 90, 273-296.

Hart, S. R., and H. Staudigel (1989), Isotopic characterization and identification of recycled components, in Crust/Mantle Recycling at Convergence Zones, edited by S. R. Hart and L. Gulen, pp. 15-28, Springer, New York.

Hart, S. R., D. C. Gerlach, and W. M. White (1986), A possible new $\mathrm{Sr}-\mathrm{Nd}-\mathrm{Pb}$ mantle array and consequences for mantle mixing, Geochim. Cosmochim. Acta, 50, 1551-1557.

Hart, S. R., E. H. Hauri, L. A. Oschmann, and J. A. Whitehead (1992), Mantle plumes and entrainment-Isotopic evidence, Science, 256, 517-520.

Hart, S. R., J. Blusztajn, H. J. Dick, P. S. Meyer, and K. Muehlenbachs (1999), The fingerprint of seawater circulation in a 500-meter section of ocean crust gabbros, Geochim. Cosmochim. Acta, 63, 4059-4080.
Hauri, E. H., and S. R. Hart (1993), Re-Os isotope systematics of HIMU and EMII oceanic island basalts from the South Pacific Ocean, Earth Planet. Sci. Lett., 114, 353-371.

Hauri, E. H., J. A. Whitehead, and S. R. Hart (1994), Fluid dynamic and geochemical aspects of entrainment in mantle plumes, J. Geophys. Res., 99, 24,275-24,300.

Hauri, E. H., J. C. Lassiter, and D. J. DePaolo (1996), Osmium isotope systematics of drilled lavas from Mauna Loa, Hawaii, J. Geophys. Res., 101, 11,793-11,806.

Hemond, C., C. W. Devey, and C. Chauvel (1994), Source compositions and melting processes in the Society and Austral Plumes (South Pacific Ocean)-Element and isotope $(\mathrm{Sr}, \mathrm{Nd}, \mathrm{Pb}, \mathrm{Th})$ geochemistry, Chem. Geol., 115, $7-45$.

Hoernle, K., Y.-S. Zhang, and D. Graham (1995), Seismic and geochemical evidence for large-scale mantle upwelling beneath the eastern Atlantic and western and central Europe, Nature, 374, 34-39.

Hofmann, A. W. (1988), Chemical differentiation of the Earth-The relationship between mantle, continental crust, and oceanic crust, Earth Planet. Sci. Lett., 90, 297-314.

Hofmann, A. W. (1997), Mantle geochemistry: The message from oceanic volcanism, Nature, 385, 219-229.

Hofmann, A. W. (2003), Sampling mantle heterogeneity through oceanic basalts: Isotopes and trace elements, in Treatise on Geochemistry: The Mantle and Core, edited by R. W. Carlson, H. D. Holland, and K. K. Turekian, pp. 61101, Elsevier, New York.

Hofmann, A. W., and W. M. White (1980), The role of subducted oceanic crust in mantle evolution, Year Book Carnegie Inst. Washington, 79, 477-483.

Hofmann, A. W., and W. M. White (1982), Mantle plumes from ancient oceanic crust, Earth Planet. Sci. Lett., 57, $421-436$

Houtermans, F. G. (1953), Determination of the age of the Earth from the isotopic composition of meteoritic lead, Nuovo Cimento, Ser. 9, 10(2), 1623-1633.

Kelley, K. A., T. Plank, J. Ludden, and H. Staudigel (2003), Composition of altered oceanic crust at ODP Sites 801 and 1149, Geochem. Geophys. Geosyst., 4(6), 8910, doi:10.1029/ 2002GC000435.

Kogiso, T., Y. Tatsumi, G. Shimoda, and H. G. Barsczus (1997), High $\mu$ (HIMU) ocean island basalts in southern Polynesia: New evidence for whole mantle scale recycling of subducted oceanic crust, J. Geophys. Res., 102, 80858103.

Lassiter, J., and E. Hauri (1998), Osmium-isotope variations in Hawaiian lavas: Evidence for recycled oceanic lithosphere in the Hawaiian plume, Earth Planet. Sci. Lett., 164, 483-496.

Le Roux, P. J., A. P. LeRoex, J. G. Schilling, N. Shimizu, W. W. Perkins, and N. J. G. Pearson (2002), Mantle heterogeneity beneath the southern Mid-Atlantic Ridge: Trace element evidence for contamination of ambient asthenospheric mantle, Earth Planet. Sci. Lett., 203, 479-498.

Mahoney, J. J., J. H. Natland, W. M. White, R. Poreda, S. H. Bloomer, R. L. Fisher, and A. N. Baxter (1989), Isotopic and geochemical provinces of the western Indian Ocean spreading centers, J. Geophys. Res., 94(B4), 4033-4052.

Mahoney, J. J., D. W. Graham, D. M. Christie, K. T. M. Johnson, L. S. Hall, and D. L. Vonderhaar (2002), Between a hotspot and a coldspot: Isotopic variation in the Southeast Indian Ridge asthenosphere, $86^{\circ} \mathrm{E}-118^{\circ} \mathrm{E}, J$. Petrol., 43, $1155-1176$.

McKenzie, D. P., and R. K. O'Nions (1983), Mantle reservoirs and ocean island basalts, Nature, 301, 229-231. 
McKenzie, D., and R. K. O’Nions (1995), The source regions of ocean island basalts, J. Petrol., 36, 133-159.

Milner, S. C., and A. P. LeRoex (1996), Isotope characteristics of the Okenyenya igneous complex, northwestern Namibia: Constraints on the composition of the early Tristan plume and the origin of the EM1 mantle component, Earth Planet. Sci. Lett., 141, 277-291.

Nakamura, Y., and M. Tatsumoto (1988), Pb, Nd, and Sr isotopic evidence for a multicomponent source for rocks of Cook-Austral Islands and heterogeneities of mantle plumes, Geochim. Cosmochim. Acta, 52, 2909-2924.

Nauret, F. (2004), Plume-ridge interaction: Example of the Réunion plume-Central Indian Ridge $\left(18^{\circ}\right.$ to $\left.20^{\circ} \mathrm{S}\right)$, dissertation, Max-Planck-Institut für Chemie, Mainz, Germany.

Niu, Y., and M. J. O'Hara (2003), Origin of ocean island basalts: A new perspective from petrology, geochemistry, and mineral physics considerations, J. Geophys. Res., 108(B4), 2209, doi:10.1029/2002JB002048.

Palacz, Z. A., and A. D. Saunders (1986), Coupled trace element and isotope enrichment in the Cook-Austral-Samoa islands, southwest Pacific, Earth Planet. Sci. Lett., 79, 270-280.

Peucker-Ehrenbrink, B., A. W. Hofmann, and S. R. Hart (1994), Hydrothermal lead transfer from mantle to continental crust: The role of metalliferous sediments, Earth Planet. Sci. Lett., 125, 129-142.

Rehkämper, M., and A. W. Hofmann (1997), Recycled ocean crust and sediment in Indian Ocean MORB, Earth Planet. Sci. Lett., 147, 93-106.

Reisberg, L., A. Zindler, F. Marcantonio, W. White, D. Wyman, and B. Weaver (1993), Os isotope systematics in ocean island basalts, Earth Planet. Sci. Lett., 120, 149-167.

Richardson, S. H., A. J. Erlank, A. R. Duncan, and D. L. Reid (1982), Correlated $\mathrm{Nd}, \mathrm{Sr}$, and $\mathrm{Pb}$ isotopic variation in Walvis Ridge basalts and implications for the evolution of their mantle source, Earth Planet. Sci. Lett., 59, 327342.

Roy-Barman, M., and C. J. Allègre (1995), ${ }^{187} \mathrm{Os} /{ }^{186}$ Os in oceanic island basalts: Tracing oceanic crust recycling in the mantle, Earth Planet. Sci. Lett., 129, 145-161.

Salters, V. J. M., and A. Stracke (2004), Composition of the depleted mantle, Geochem. Geophys. Geosyst., 5, Q05B07, doi:10.1029/2003GC000597.

Salters, V. J. M., and W. M. White (1998), Hf isotope constraints on mantle evolution, Chem. Geol., 145, 447-460.

Staudigel, H., G. R. Davies, S. R. Hart, K. M. Marchant, and B. M. Smith (1995), Large scale isotopic Sr, Nd and O isotopic anatomy of altered oceanic crust: DSDP/ODP sites 417/418, Earth Planet. Sci. Lett., 130, 169-185.

Staudigel, H., T. Plank, W. M. White, and H. U. Schmincke (1996), Geochemical fluxes during seafloor alteration of the basaltic upper crust: DSDP sites 417 and 418, in Subduction: Top to Bottom, Geophys. Monogr. Ser., vol. 96, edited by G. E. Bebout et al., pp. 19-38, AGU, Washington, D. C.

Stracke, A., M. Bizimis, and V. J. M. Salters (2003a), Recycling oceanic crust: Quantitative constraints, Geochem. Geophys. Geosyst., 4(3), 8003, doi:10.1029/2001GC000223.

Stracke, A., A. Zindler, V. J. M. Salters, D. McKenzie, J. Blichert-Toft, F. Albarède, and K. Grönvold (2003b), Theistareykir revisited, Geochem. Geophys. Geosyst., 4(2), 8507, doi:10.1029/2001GC000201.

$\mathrm{Su}$, Y. J. (2002), Mid-ocean ridge basalt trace element systematics: Constraints from database management, ICP-MS analyses, global data compilation and petrologic modeling, Ph.D. thesis, Columbia Univ., New York.
Sun, S. S. (1980), Lead isotopic study of young volcanic rocks from mid-ocean ridges, ocean islands and island arcs, Philos. Trans. R. Soc. London, Ser. A, 297, 409-445.

Sun, S.-S., and W. F. McDonough (1989), Chemical and isotopic systematics of oceanic basalts: Implications for mantle composition and processes, in Magmatism in the Ocean Basins, edited by A. D. Saunders and M. J. Norry, Geol. Soc. Spec. Publ., 42, 313-345.

Tatsumoto, M. (1978), Isotopic composition of lead in oceanic basalt and its implication to mantle evolution, Earth Planet. Sci. Lett., 38, 63-87.

Thirlwall, M. F. (1995), Generation of the Pb isotopic characteristics of the Iceland plume, J. Geol. Soc. London, 152, 991-996.

Thirlwall, M. F. (1997), Pb isotopic and elemental evidence for OIB derivation from young HIMU mantle, Chem. Geol., $139,51-74$.

van der Hilst, R., S. Widiyantoro, and E. R. Engdahl (1997), Evidence for deep mantle circulation from global tomography, Nature, 386, 578-584.

Vidal, P. (1992), Mantle: More HIMU in the future?, Geochim. Cosmochim. Acta, 56, 4295-4299.

Vidal, P., and L. Dosso (1978), Core formation: Catastrophic of continuous? $\mathrm{Sr}$ and $\mathrm{Pb}$ isotope geochemistry constraints, Geophys. Res. Lett., 5, 169-172.

Vidal, P., C. Chauvel, and R. Brousse (1984), Large mantle heterogeneity beneath French Polenesia, Nature, 307, 536538.

Vollmer, R. (1977), Terrestrial lead isotopic evolution and formation of the Earth's core, Nature, 270, 144-147.

Weaver, B. L. (1991), The origin of ocean island basalt end-member compositions: Trace element and isotopic constraints, Earth Planet. Sci. Lett., 104, 381-397.

Wilson, M., J. M. Rosenbaum, and E. A. Dunworth (1995), Melilitites: Partial melts of the thermal boundary layer?, Contrib. Mineral. Petrol., 119, 181-195.

Woodhead, J. D. (1996), Extreme HIMU in an oceanic setting: The geochemistry of Mangaia island (Polynesia), and temporal evolution of the Cook-Austral hot spot, J. Volcanol. Geotherm. Res., 72, 1-19.

Workman, R. K., S. R. Hart, M. Jackson, M. Regelous, K. A. Farley, J. Blusztajn, M. Kurz, and H. Staudigel (2004), Recycled metasomatized lithosphere as the origin of the Enriched Mantle II (EM2) end-member: Evidence from the Samoan Volcanic Chain, Geochem. Geophys. Geosyst., 5, Q04008, doi:10.1029/2003GC000623.

Wörner, G., A. Zindler, H. Staudigel, and H. U. Schmincke (1986), Sr, Nd, and Pb isotope geochemistry of Tertiary and Quaternary alkaline volcanics from West Germany, Earth Planet. Sci. Lett., 79, 107-119.

Zartman, R. E., and S. M. Haines (1988), The plumbotectonic model for $\mathrm{Pb}$ systematics among major terrestrial reservoirs-A case for bi-directional transport, Geochim. Cosmochim. Acta, 52, 1327-1339.

Zimmer, M., A. Kroener, K. P. Jochum, T. Reischmann, and W. Todt (1995), The Gabal Gerf complex: A precambrian N-MORB ophiolite in the Nubian shield, NE Africa, Chem. Geol., 123, 29-51.

Zindler, A., and S. Hart (1986), Chemical geodynamics, Annu. Rev. Earth Planet. Sci., 14, 493-571.

Zindler, A., S. R. Hart, F. A. Frey, and S. P. Jakobsson (1979), $\mathrm{Nd}$ and $\mathrm{Sr}$ isotope ratios and rare-earth element abundances in Reykjanes Peninsula basalts-Evidence for mantle heterogeneity beneath Iceland, Earth Planet. Sci. Lett., 45, 249-262. 